\title{
Harmonizing Global Care Policy? \\ Care and the Commission on the Status of Women
}

Kate Bedford 
This United Nations Research Institute for Social Development (UNRISD) Programme Paper has been produced with the support of the United Nations Development Programme (UNDP), Japan/WID Fund, the International Development Research Centre (Canada), and the Swiss Agency for Development and Cooperation (SDC). UNRISD also thanks the governments of Denmark, Finland, Mexico, South Africa, Sweden, Switzerland and the United Kingdom for the core funding they provided in 2009.

Copyright (c) UNRISD. Short extracts from this publication may be reproduced unaltered without authorization on condition that the source is indicated. For rights of reproduction or translation, application should be made to UNRISD, Palais des Nations, 1211 Geneva 10, Switzerland. UNRISD welcomes such applications.

The designations employed in UNRISD publications, which are in conformity with United Nations practice, and the presentation of material therein do not imply the expression of any opinion whatsoever on the part of UNRISD concerning the legal status of any country, territory, city or area or of its authorities, or concerning the delimitation of its frontiers or boundaries.

The responsibility for opinions expressed rests solely with the author(s), and publication does not constitute endorsement by UNRISD. 


\section{Contents}

$\begin{array}{ll}\text { Acronyms } & \text { ii }\end{array}$

$\begin{array}{ll}\text { Acknowledgements } & \text { ii }\end{array}$

Summary/Résumé/Resumen iii

Summary iii

Résumé

Resumen $\quad v$

$\begin{array}{lr}\text { Introduction } & 1\end{array}$

Section 1. Background on the CSW 22

Section 2. Framing the Theme: Gender Policy Entrepreneurship, Care and the CSW

Section 3. Key Achievements

Global recognition of care as a core political issue, especially in relation to HIV, for which governments are responsible

Strengthened NGO work on care

Section 4. What the Care Conversation Could Enable in the Future 17

Disability and care: "The trend is upwards"

Diversity of family formations in care conversations

Conclusion: Toward Some Reframing

Bibliography

UNRISD Programme Papers on Gender and Development 


\section{Acronyms}

$\begin{array}{ll}\text { ACC } & \text { Anglican Consultative Council } \\ \text { AIDS } & \text { acquired immunodeficiency syndrome } \\ \text { CEDAW } & \text { Convention on the Elimination of Discrimination against Women } \\ \text { CRPD } & \text { Convention on the Rights of Persons with Disabilities } \\ \text { CSW } & \text { Commission on the Status of Women } \\ \text { DAW } & \text { Division for the Advancement of Women (United Nations) } \\ \text { ECOSOC } & \text { United Nations Economic and Social Council } \\ \text { EGM } & \text { Expert Group Meeting } \\ \text { EU } & \text { European Union } \\ \text { HIV } & \text { human immunodeficiency virus } \\ \text { ICPD } & \text { International Conference on Population and Development } \\ \text { ILO } & \text { International Labour Organization } \\ \text { NGO } & \text { non-governmental organization } \\ \text { PFA } & \text { Platform for Action } \\ \text { UK } & \text { United Kingdom } \\ \text { UN } & \text { United Nations } \\ \text { UNAIDS } & \text { Joint United Nations Programme on HIV/AIDS } \\ \text { UNIFEM } & \text { United Nations Development Fund for Women } \\ \text { UNRISD } & \text { United Nations Research Institute for Social Development } \\ \text { US } & \text { United States } \\ \text { WHO } & \text { World Health Organization }\end{array}$

\section{Acknowledgements}

I would like to express my deepest thanks to the interviewees who gave their time to answer my questions, and to staff at the Division for the Advancement of Women (DAW) who provided crucial background material for the paper. Thanks also to Linda Pitt, who transcribed the tapes. Helpful feedback was provided by Doris Buss, Rosemary Hunter, Shahra Razavi, Silke Staab, eight interviewees and two anonymous reviewers. I thank the organizers of the IDS workshops on sexuality and development (Cape Town) and Queerying the Global South (Manchester) for the opportunity to present the draft there, and participants at both workshops for engaging with the arguments in the paper. All errors are my own. 


\section{Summary/Résumé/Resumen}

\section{Summary}

In March 2009 Member States of the United Nations met in New York at the Commission on the Status of Women (CSW) to discuss, among other things, the priority theme of "The equal sharing of responsibilities between women and men, including care-giving in the context of HIV/AIDS". This meeting provided an unprecedented opportunity to focus the international community's attention on care issues and to generate Agreed Conclusions that would lay out a roadmap for care policy, potentially influencing national legislation, policies adopted by UN entities and future international agreements. Using interviews with participants and an overview of official documentation, this paper seeks to summarize the achievements of the 2009 CSW, and to suggest where policy conversations about care might usefully focus next.

More specifically, the paper aims to contribute to three key objectives: (i) identify the narrative(s) of how the policy frame of equal sharing of responsibilities, including care-giving in the context of HIV/AIDS, came into being; (ii) identify the policy alliances generated through that frame; and (iii) identify the key achievements forged at the 53rd session, while examining what the Agreed Conclusions might make possible to say and do around care issues in the future. In this way it aims to provide a supportive and critical examination of the emerging global policy agenda on care issues as crystallized in the meetings around the 2009 CSW.

With regard to the achievements, the paper argues that the frame of care, linked as it was to the equal sharing of responsibility between men and women, proved an exceptionally expansive one. It successfully united a wide range of actors, including conservative faith-based actors who had mobilized against other gender equality initiatives in the past. This expansive frame facilitated three key advances in care policy at the 53rd session: (i) consensus among Member States and other actors on the significance of care across the UN system, especially in relation to HIV; (ii) consensus on a strong state responsibility; and (iii) consensus on the centrality of caregivers' participation in debates over policy. These advances may prove significant in increasing attention to care within the United Nations, defending care services from state cutbacks in a recession, and helping civil society actors mobilize around care, especially as related to HIV. In addition, the agreements made at the 2009 CSW may represent the emergence of a new consensus around the importance of economic justice issues in gender equality venues, given the foregrounding of state services and the challenge to free-market models of growth witnessed there.

In an attempt to consider where care conversations might usefully focus next, the paper closes with a discussion of two issues that received less attention at the 2009 CSW: disability and diversity of family formation. These two issues are highly relevant to care debates, at the UN level and elsewhere, and can help move global policy forward in fruitful directions. That said, policy conversations will need to be reframed to take them into account. This task will in some ways challenge the consensus on care forged at the 2009 CSW. For example, the progress made in carrying forward the global gender equality project via a unifying focus on care is in part based on a consensus about care-givers as the central actors, a position challenged by disability activism and scholarship. Likewise, the agreements forged at the 2009 CSW in many ways entrenched the notion that privatized nuclear family units were a universally desirable model for care provision, a notion challenged by a range of actors who recognize the role of extended family members in care, and/or who want to secure more support for the diverse forms through which care is provided. A reframing of care debates will be necessary if new alliances with such actors are to be forged and strengthened. While the paper seeks to explicate the immense value of the Agreed Conclusions forged at the 2009 CSW for future efforts to secure care services, it also aims to explore the limitations of those agreements and highlight the importance of continuing the conversation on care to grapple with current exclusions. 
Kate Bedford is a Lecturer and Research Fellow at the Kent Law School (University of Kent) in the United Kingdom.

\section{Résumé}

En mars 2009, les Etats membres des Nations Unies siégeant à la Commission de la condition de la femme à New York ont débattu, entre autres, du thème prioritaire, "Le partage, dans des conditions d'égalité, des responsabilités entre les femmes et les hommes, en particulier des soins dispensés dans le contexte du VIH/sida". Cette réunion a été une occasion sans précédent d'attirer l'attention de la communauté internationale sur les questions des soins et d'établir, par ses "conclusions concertées", une feuille de route pour une politique des soins qui puisse influencer le droit national, la politique adoptée par les entités de l'ONU et de futurs accords internationaux. A partir d'entretiens avec des participants et d'une étude de l'ensemble de la documentation officielle, l'auteur s'efforce de résumer les résultats obtenus lors de la session 2009 de la Commission de la condition de la femme et de suggérer des sujets sur lesquels pourraient utilement porter les prochaines discussions sur une politique des soins.

Plus précisément, elle se fixe dans ce document trois objectifs principaux: (i) retrouver le ou les cheminements par lesquels on en est arrivé à choisir pour cadre politique le partage, dans des conditions d'égalité, des responsabilités entre les femmes et les hommes, en particulier des soins dispensés dans le contexte du VIH/sida; (ii) mettre au jour les alliances politiques générées par ce cadre; et (iii) dégager, après la cinquante-troisième session, les principales avancées pour ceux qui y ont participé et ce que les conclusions concertées pourraient permettre de dire et de faire à l'avenir sur les questions de soins. Elle vise ainsi dans ce document à proposer un examen à la fois critique et positif du programme politique mondial qui est en train de se constituer sur les questions de soins, tel qu'il ressort des réunions qui se sont tenues autour de la session 2009 de la Commission de la condition de la femme.

S'agissant des résultats, l'auteur fait valoir que le cadre des soins, lié comme il l'était au partage, dans des conditions d'égalité, des responsabilités entre les femmes et les hommes, s'est révélé exceptionnellement large. Il a réussi à unir des acteurs très divers, dont les acteurs religieux conservateurs, qui, dans le passé, s'étaient mobilisés contre d'autres initiatives relatives à l'égalité entre hommes et femmes. Ce cadre extensible a permis trois avancées majeures dans la politique des soins à la cinquante-troisième session: (i) un consensus entre les Etats membres et d'autres acteurs sur l'importance des soins dans tout le système des Nations Unies, en particulier par rapport au VIH; (ii) un consensus sur la forte responsabilité de l'Etat; et (iii) un consensus sur l'importance de la participation des prestataires de soins aux débats sur les politiques. Ces avancées peuvent se révéler appréciables en attirant davantage l'attention sur les soins, dans le système des Nations Unies, en défendant les services de soins contre les restrictions budgétaires en période de récession et en aidant les acteurs de la société civile à se mobiliser autour des soins, en particulier ceux qui sont dispensés dans le contexte du VIH. De plus, les accords passés à la session 2009 de la Commission de la condition de la femme pourraient annoncer un autre consensus, qui se formerait autour de l'importance des questions de justice économique dans les domaines investis par l'égalité entre hommes et femmes, étant donné le rôle de pionnier des services de l'Etat et la contestation des modèles de croissance libéraux qui s'en dégage.

Tentant de déterminer sur quels sujets pourraient porter les prochaines discussions sur les soins, l'auteur conclut en traitant de deux questions qui ont moins retenu l'attention à la session 2009 de la Commission de la condition de la femme: l'invalidité et la diversité des formes que revêt la famille. Ces deux questions touchent de près à celles des soins, telles qu'elles sont débattues aux Nations Unies et ailleurs, et peuvent faire avancer la politique mondiale dans des directions très utiles. Cela dit, il faudra recadrer les politiques pour prendre les soins en considération. Cela va, à certains égards, remettre en question le consensus sur les soins qui s'est dégagé à la session 2009 de la Commission de la condition de la femme. Par exemple, les progrès faits dans le projet mondial d'égalité entre les hommes et les femmes grâce à l'accent 
mis les soins, qui a été un facteur d'unification, reposent d'une part sur une entente pour considérer les prestataires de soins comme les acteurs centraux, position que contestent les milieux "handicapés" militants et les intellectuels. De même, les accords passés à la Commission de la condition de la femme entérinent à bien des égards l'idée que, pour la prestation des soins, la famille nucléaire, comme espace privatisé, est un modèle qu'il est souhaitable d'étendre au monde entier, ce que contestent divers acteurs qui reconnaissent le rôle joué par la famille élargie dans les soins et/ou qui veulent que les diverses formes de prestation de soins soient davantage soutenues. Il sera nécessaire de recadrer les débats sur les soins si l'on veut nouer des alliances avec ces acteurs et les consolider. Si l'auteur s'emploie à expliciter l'immense utilité des conclusions concertées, adoptées à la session 2009 de la Commission de la condition de la femme, pour les efforts qui seront déployés à l'avenir afin d'obtenir des services de soins, elle entend aussi en explorer les limites et montrer qu'il importe de poursuivre les discussions sur les soins pour mettre fin aux exclusions actuelles.

Kate Bedford est Maître de conférences et chargée de recherche à la faculté de droit de l’Université du Kent au Royaume-Uni.

\section{Resumen}

En marzo de 2009, los Estados Miembros de las Naciones Unidas se reunieron en Nueva York, en el ámbito de la Comisión de la Condición Jurídica y Social de la Mujer, para debatir, entre otros asuntos, el tema del "Reparto equitativo de las responsabilidades entre mujeres y hombres, incluidos los cuidados prestados en el contexto del VIH/SIDA". Esta reunión brindó una oportunidad sin precedentes a la comunidad internacional para centrar su atención en los problemas del cuidado y generar una serie de Conclusiones Convenidas que definirían una hoja de ruta para la política de cuidados que podría incidir en las legislaciones nacionales, la política adoptada por las entidades de las Naciones Unidas y futuros convenios internacionales. A partir de entrevistas a cierto número de participantes en la conferencia y un examen general de la documentación oficial, el presente trabajo se propone resumir los logros de dicha reunión y proponer algunos puntos que podrían abordarse en las próximas deliberaciones sobre el cuidado.

Este documento busca específicamente contribuir al logro de tres objetivos clave: (i) identificar la parte explicativa del origen del marco de política del reparto equitativo de responsabilidades, incluidos los cuidados prestados en el contexto del VIH/SIDA; (ii) identificar las alianzas de política que se generaron por medio de ese marco; y (iii), definir, tras la conclusión del $53^{\circ}$ período de sesiones, cuáles fueron, de acuerdo con los participantes, los principales avances y qué conclusiones convenidas podrían permitir el decir y hacer algo sobre los cuidados en el futuro. El documento busca con ello aportar un análisis crítico y de apoyo a la nueva agenda internacional sobre los problemas del cuidado que tomara forma durante las reuniones celebradas en el contexto del período de sesiones de la Comisión en 2009.

Con respecto a los logros, el documento sostiene que el marco de los cuidados, enfocado desde la óptica del reparto equitativo de las responsabilidades entre mujeres y hombres, resultó ser un marco excepcionalmente amplio. En efecto, logró unir a una amplia gama de actores, incluidos los actores religiosos conservadores que en el pasado se habían movilizado en contra de otras iniciativas de igualdad de género. Este marco más amplio facilitó tres avances clave en la política del cuidado durante el $53^{\circ}$ período de sesiones: (i) consenso entre los Estados Miembros y otros actores sobre la importancia del cuidado en todo el sistema de las Naciones Unidas, en especial en relación con el VIH; (ii) consenso en torno a la responsabilidad substancial del Estado; y (iii) consenso en cuanto a la importancia fundamental de la participación de los proveedores de cuidados en los debates sobre las políticas. Estos avances pueden resultar significativos para aumentar la atención que se presta al cuidado en las Naciones Unidas, proteger los servicios de cuidados de los recortes que pudiera hacer el Estado ante una recesión y ayudar a los actores de la sociedad civil a movilizarse en torno al cuidado, sobre todo en relación con el VIH. Además, los acuerdos alcanzados en la reunión de la Comisión sobre la 
Condición Jurídica y Social de la Mujer en 2009 podrían representar el surgimiento de un nuevo consenso en torno a la importancia de los temas de justicia económica en contextos de igualdad de género, habida cuenta de la preponderancia conferida a los servicios públicos y el cuestionamiento de los modelos de crecimiento basados en el mercado libre que se observaran en la mencionada reunión.

En un intento por determinar los aspectos que pudieran abordarse en las futuras conversaciones sobre el cuidado, el documento concluye con un análisis de dos problemas que recibieron menos atención en las reuniones de la Comisión en 2009: la discapacidad y la diversidad de la formación familiar. Estos dos temas son sumamente pertinentes para los debates sobre el cuidado, tanto a nivel de las Naciones Unidas como en otras instancias, y pueden contribuir a llevar la política internacional sobre este tema en direcciones fructíferas. No obstante, es menester 'reenmarcar' las conversaciones de política para tomar en cuenta estos dos aspectos, lo que de alguna forma pondría en tela de juicio el consenso que sobre el cuidado se forjase en la reunión de la Comisión en 2009. Por ejemplo, los adelantos que se han logrado con el proyecto internacional sobre igualdad de género a través de un enfoque unificado sobre el cuidado descansa parcialmente en un consenso en torno a los proveedores de cuidados como los actores centrales del proceso, posición esta a la que se oponen los activistas e intelectuales del tema de las discapacidades. De forma análoga, los acuerdos alcanzados en la Comisión de la Condición Jurídica y Social de la Mujer afianzaron la noción de que las familias nucleares privatizadas eran un modelo universal conveniente para la provisión del cuidado, idea que cuestionan numerosos actores que reconocen el papel de las familias extensas en el cuidado y/o que quieren asegurar un apoyo mayor a la diversas maneras de proveer los cuidados. Será necesario reformular el marco de los debates sobre el cuidado si se pretende forjar y fortalecer nuevas alianzas con estos actores. Si bien el documento busca explicar el inmenso valor que las conclusiones convenidas en las reuniones de la Comisión de la Condición Jurídica y Social de la Mujer en 2009 tienen para las medidas futuras dirigidas a garantizar los servicios de cuidados, también se propone explorar las limitaciones de dichos acuerdos y resaltar la importancia de continuar el diálogo sobre el cuidado para hacer frente a las exclusiones actuales.

Kate Bedford trabaja como profesora e investigadora en la Escuela de Derecho de la Universidad de Kent, en el Reino Unido. 


\section{Introduction}

In March 2009, Member States of the United Nations met in New York at the Commission on the Status of Women (CSW) to discuss, among other things, the priority theme of "The equal sharing of responsibilities between women and men, including care-giving in the context of HIV/AIDS". This meeting provided an unprecedented opportunity to focus the international community's attention on care issues and to generate Agreed Conclusions that would lay out a roadmap for care policy, potentially influencing national legislation, policies adopted by UN entities and future international agreements. The commitments made by Member States will, if implemented, open a new chapter in UN-level work on gender relations, poverty, HIV/AIDS provision and workers' rights. This paper examines the history and consequences of this process. It aims, first, to improve our understanding of the CSW, since its processes and outcomes require clarification. More specifically, though, the paper sets out to contribute to three additional objectives: (i) identify the narrative(s) of how the policy frame of equal sharing of responsibilities, including care-giving in the context of HIV/AIDS, came into being; (ii) identify the policy alliances generated through that frame; and (iii) identify, in the aftermath of the 53rd session, what those involved understood to be the major steps forward, and what the Agreed Conclusions might make possible to say and do around care issues in the future. Research involved a review of documentation related to the 53rd session of the CSW ${ }^{1}$ and interviews with participants and other informants. ${ }^{2}$

Based on this research, the paper argues that the frame of care, linked as it was to the equal sharing of responsibility between men and women, proved an exceptionally expansive one. It successfully united a wide range of actors, including conservative faith-based actors who had mobilized against other gender equality initiatives in the past. This expansive frame facilitated three key advances in care policy at the 53rd session: (i) consensus among Member States and other actors on the significance of care across the UN system, especially in relation to HIV; (ii) consensus on a strong state responsibility; and (iii) consensus on the centrality of care-givers' participation in debates over policy. These advances may prove significant in increasing attention to care within the United Nations, defending care services from state cutbacks in a recession, and helping civil society actors mobilize around care, especially in relation to HIV. The paper closes, though, with a discussion of two issues that received less attention at the 2009 CSW: disability and variations in family formation. These two issues are highly relevant to care debates, at the UN level and elsewhere, and can help move global policy forward in fruitful directions. However, reframing existing policy conversations to take them into account will pose a serious-though by no means insurmountable-challenge to the consensus on care forged at the 2009 CSW. Because the progress made in carrying forward the global gender equality project via a unifying focus on care is in part based on a consensus regarding care-givers as the central actors (a position challenged by disability activism and scholarship), and on a universal model of a privatized malefemale couple sharing love and labour (a position challenged by sexuality activism and scholarship), a reframing of care debates will be necessary if new alliances with other actors are to be forged. While the paper seeks to explicate the immense value of the Agreed Conclusions forged at the CSW for future efforts to secure care services, it also aims to explore the limitations of those agreements and highlight the importance of continuing the conversation on care to grapple with current exclusions.

\footnotetext{
1 This includes the Secretary-General's reports; the Agreed Conclusions; the information provided about the priority theme on the CSW web site; the online discussion (and the summary report thereof); the report of the Expert Group Meeting and the papers prepared by experts; and the statements at the CSW by UN entities, delegates of Member States and regions, and non-governmental organizations (NGOs).

2 These included members of state delegations; UN personnel; independent experts and observers involved in the meetings; participants in the online discussion; and NGO representatives. Eighteen interviews were conducted by telephone in July and August 2009; all but one were recorded.
} 


\section{Section 1. Background on the CSW}

The CSW was established in 1946, and is the United Nations principal norm-setting and policymaking body on issues of gender equality and the advancement of women. ${ }^{3}$ The Commission is made up of 45 representatives of Member States. Representatives of five regional groups constitute the Bureau that organizes the annual meetings of the Commission. Support and servicing of the CSW is provided by the Division for the Advancement of Women (DAW), part of the Department of Economic and Social Affairs. The CSW's current working methods involve a strong focus on promoting and monitoring implementation of gender agreements at the national level, and playing a catalytic role in promoting gender equality through enhancing collaboration with other bodies (Lucas 2009:3).

The CSW's most important activity is its annual March meeting at UN headquarters in New York, coinciding with International Women's Day. At this meeting, delegates of Member States gather "to evaluate progress on gender equality, identify challenges, set global standards and formulate concrete policies to promote gender equality and advancement of women worldwide". ${ }^{4}$ More specifically, after the 1995 Beijing Conference the CSW adopted new working methods designed to move the international community forward on the Platform for Action (PFA), ${ }^{5}$ including through the adoption of negotiated conclusions on thematic areas of focus (CSW 2006:16). Themes are set several years in advance, after being discussed within the Bureau and after consultation with other UN entities and non-governmental organizations (NGOs), including those represented in the NGO Committee on the Status of Women. The Agreed Conclusions resulting from the CSW's meetings are designed to "contain an analysis of the priority theme of concern and a set of concrete recommendations for Governments, intergovernmental bodies and other institutions, civil society actors and other relevant stakeholders, to be implemented at the international, national, regional and local level". ${ }^{6}$ They are put forward for adoption as resolutions of the UN Economic and Social Council (ECOSOC), increasing their authority and weight. ${ }^{7}$

Although not binding in the way that treaties are, and lacking the threat of sanctions, the Agreed Conclusions forged at the CSW play a key role in producing "soft law" on gender and in forging international norms. ${ }^{8}$ Delegates are thus involved in the process of drawing what Doris Buss (2004:61) calls an international social policy roadmap, wherein an international consensus is formed around new issues. This policy roadmap can, potentially, take on legal significance by defining international expectations, and hence possibly shaping future agreements, on the theme under consideration. ${ }^{9}$ The CSW will return to the care theme in two or three years to review implementation of the policy recommendations and identify remaining gaps and challenges.

That said, while the negotiation of Agreed Conclusions by Member States is a key focus of the CSW's work, a lot more goes on at, alongside, and in preparation for, the annual meetings. Relevant UN entities attend and may have their work influenced by the conversations taking place, and invited experts participate in discussions on the theme at the CSW. NGO

\footnotetext{
3 See www.un.org/womenwatch/daw/csw/index.html\#about, accessed on 29 June 2009. For the history of the CSW, see CSW (2006); Laville (2008); Gaer (2009).

4 www.un.org/womenwatch/daw/csw/index.html\#about, accessed on 29 June 2009.

5 This mandate was later extended to include implementation of the UN's 23rd special session of the General Assembly meeting in 2000 on review and appraisal of the implementation of the PFA, and considering future actions and initiatives. See CSW (2006).

6 CSW, www.un.org/womenwatch/daw/csw/index.html\#about, accessed on 20 July 2009.

7 As the President of ESOSOC notes "The policy recommendations will guide the work of ECOSOC and its subsidiary bodies" (Lucas 2009:2). See also the examples given by the Assistant Secretary-General/Special Adviser on Gender Issues and Advancement of Women on how previous CSW sessions have fed in to the outcomes of other intergovernmental processes, including the Declaration of the Doha Review Conference and the Accra Agenda for Action (Mayanja 2009:1).

8 See Riles (2000); Gaer (2009); Merry (2000); Finnemore (1996) on soft law, international organizations and the production of norms.

9 Doris Buss, personal communication, 6 October 2009.
} 
representatives also gather in New York to hold parallel events, most of which are held in buildings around the official venue (including the Church centre). Over 200 such meetings were held at the 2009 CSW, creating an opportunity for researchers, policy makers, civil society representatives and activists to link up and exchange ideas. Additionally, independent experts and NGOs are invited to participate in wider debates on the theme outside the annual meeting process itself, through mechanisms such as an online discussion forum, ${ }^{10}$ and an Expert Group Meeting (EGM) held in the autumn before the March meeting that results in an independent report for the UN Secretary-General. These are not mechanisms of the CSW, but are part of the preparatory process organized by DAW that feed in to the discussions at the CSW.

Several interviewees felt that these processes of civil society engagement and ideas exchange were as, if not more, important than the interstate negotiations:

This is the primary UN forum for women's NGO involvement, I mean this is basically it, in terms of large scale civil society participation. This is the women's thing, so to speak... Not that many people dive into the government work; proportionally, most people are at the CSW for networking and education purposes rather than work with governments or policy work" (Interviewee 14).

I did attend some of the sessions when they had [expert] panel discussions. Actually, I think that is in many ways more interesting, in the sense that, you know, when you are listening to country statements a lot of the countries may not be in your league or they may be from a specific region and they are not all necessarily relevant to us. I think the panels are usually pretty good and they have pretty solid speakers and it's interesting (Interviewee 2).

I'd say some of the best conversations are happening in the Church centre, it's really well informed and engaged (Interviewee 11).

The CSW is thus a complex, hybrid event, sprawling out of the United Nations headquarters, extending back long before March every year, and far from contained within the intergovernmental negotiations about official Agreed Conclusions. This complexity is crucial to consider when asking about the impact of the 2009 CSW on transnational conversations about care.

\section{Section 2. Framing the Theme: Gender Policy Entrepreneurship, Care and the CSW}

Framing means connecting beliefs about social actors and beliefs about social relations into more or less coherent packages that define what kinds of action are necessary, possible and effective for particular actors. The point of frames is that they draw connections, identify relationships and create perceptions of social order out of the variety of possible mental representations of reality swirling around social actors (Marx Ferree 2009:89).

I was concerned that the issue of care become an issue of policy. The popular discourse on care is that it is some voluntary experience...that this is an organic role for women to play... What was central to me was to frame it differently, as an issue of policy (Interviewee 10, original vocal emphasis).

A range of researchers have examined how best to promote gender priorities within mainstream organizations, such as UN entities. ${ }^{11}$ They often use "integrationist tactics" (Kabeer

\footnotetext{
${ }^{10}$ For example, 1,243 participants registered for the online forum at the 2009 CSW.

11 Staudt 2002; Kabeer and Subrahmanian 2000; Hafner-Burton and Pollack 2002; Prügl and Lustagarten 2006.
} 
2000:33) to show how women's advancement can serve existing institutional agendas. Thus Carol Miller and Shahra Razavi (1998:7), borrowing from Nelson Polsby, argued several years ago that insider advocates act as "feminist policy entrepreneurs", framing their issues in ways sensitive to institutional context (see also Goetz 1997). Gender advocates do not control or impose the frame in this understanding. They may try to shape it to fit the constraints within which they are operating, but usually their attempts to "sell" the relevance of a particular topic within mainstream organizations reveal more about those organizations than about gender staff and their own commitments. Attention to framing - to how policy problems are defined, how the solutions are constructed, and who has a voice in that process (Lombardo et al. 2009b:10) is thus an important part of feminist policy analysis, revealing the opportunities and limitations evident within particular institutional contexts for progress on gender issues. A recent collection of work on this issue defines a political frame as "'an organizing principle that transforms fragmentary or incidental information into a structured and meaningful policy problem, in which a solution is implicitly or explicitly included"' (Verloo, quoted in Lombardo et al. 2009b:11). Frames do not precede political practice, in this view; rather they are a form of political practice (Poguntke 2009:xv). This section examines how the theme of the 53rd session was framed, particularly in terms of how the theme was explained vis-à-vis past international agreements, and who it brought together. As explained in later sections, this can aid analysis of how the key achievements of the 2009 CSW were secured, and it facilitates conversation about steps forward.

Building a frame about any issue at the CSW is a complex intersubjective process, involving many different actors. Thus this paper examines the arguments used to legitimate a focus on care by experts, gender bureaucrats within the United Nations helping to facilitate the Commission's work, NGOs and Member States. In other words, it examines the stories told about why care matters, and how it links to other, widely accepted, priorities. ${ }^{12}$ One caveat is perhaps in order in this regard. Reference to gender policy entrepreneurship in the CSW may seem counter-intuitive, since gender staff have limited power, and considerable emphasis is placed on the fact that Member States forge the agreements. While I do not wish to overstate the role of gender bureaucrats in this site, then, I wish to examine what framing work is involved in the CSW's attempt to play a catalytic role in gender equality. When Member States arrive in March there is already a draft text for them to consider, for example, prepared by the Bureau, along with a "backgrounder" text on the theme prepared by the CSW, and a report from the Secretary-General based in part on the report from the EGM organized the previous year by the DAW. ${ }^{13}$ The UN gender staff involved in the CSW thus play a complex, facilitating role for Member States, explaining the relevance of the theme to them, choosing-in negotiation with other actors - the experts who attend the EGM and the CSW itself; and assisting in the drafting of key early language for Member States to debate and expand upon. This is all classic framing work.

The priority theme for the 2009 CSW was chosen in 2006 when the Commission adopted its multiyear programme of work (ECOSOC resolution 2006/9). According to the DAW, which prepared briefing notes on the development of the theme:

The selection of a topic by the CSW is guided by the extent to which a) the
issue remains a priority at national level; b) it has been taken up by the CSW
since 1995; and c) consideration of the issue can feed into other forthcoming
intergovernmental processes. The division of unpaid work between women
and men, including care-work, was clearly identified as an obstacle to
women's participation in all spheres of life in the Beijing Platform for Action
adopted at the Fourth World Conference on Women in 1995 and the outcome
of the 23rd special session of the General Assembly in 2000 . The International
Conference on Population and Development (1994) and the World Summit for

\footnotetext{
${ }^{12}$ For more on policy stories see, for example, Sending (2004).

${ }^{13}$ This is in addition to other available material such as the report from the EGM, statements submitted from various NGOs, and so onMember States are much less likely to read this material.
} 
Social Development (1995) also raised this issue. Already in 1981, the ILO [International Labour Organization] had adopted Convention No. 156 on Workers with Family Responsibilities...

The issue of unpaid work, including caregiving, was clearly of importance at national level, because of the aging of societies in some regions, the fertility declines in others, and the impact of HIV/AIDS on caregiving in particular in Africa. The issue had only received specific focus in the CSW once, in 1996 when the Commission discussed and adopted agreed conclusions on 'Child and dependent care, including sharing of work and family responsibilities.' Consideration of the theme provided an opportunity to follow-up on the implementation of agreed conclusions the CSW had adopted on the role of men and boys in achieving gender equality and on women (2004), [and on] the girl child and HIV/AIDS (2001). In addition, by considering this theme, the CSW could contribute to follow-up to the Comprehensive Review of Progress achieved in realizing the targets set out in the Declaration of Commitments on HIV/ AIDS (DAW 2009a:n.p.).

As is clear in this explanation, and as several interviewees noted, the theme of the 53rd session was actually about the interrelation of three themes (equal sharing of responsibility, care and $\mathrm{HIV}$ / AIDS). Binding them together into a coherent frame that could produce action-oriented conclusions was a core challenge, since each of the components of the theme had its own trajectory within UN debate, and its own dominant policy narratives and authoritative texts. For example, while the language of the equal sharing of responsibilities came from the PFA, it was understood there to include political participation and equal sharing of leadership roles; it was not only about care. More recently, the language of equal sharing has taken on a valence associated with debates about male inclusion in gender equality measures, a shift which has given space to some NGOs working on changing men. The ILO, in turn, approached the theme via its initiatives on work and family responsibilities, and via its efforts to better protect domestic workers' rights (Addati and Cassirer 2008:7). Meanwhile the Joint United Nations Programme on HIV/AIDS (UNAIDS) referenced the General Assembly meeting on HIV/ AIDS in 2001, and the 2006 commitment on universal access to comprehensive HIV prevention, treatment, care and support (Sidibé 2009:3). The European Union's (EU) Member States referenced their attempts to reform the legal framework to support reconciliation of work and private life (Kocáb 2009:2), while a number of African country statements focused on homebased care workers and People Living With HIV/AIDS (Tsiane 2009). In turn, the conversations that have been circulating among gender and development specialists about care have been heavily influenced by feminist economists and their debates about gender budgeting, how to measure and count unpaid work, and the consequences of neoliberal policies for the care sector. As several participants noted, not all of these relevant conversations had been conducted using the language of equal sharing of responsibilities, or even of care:

We haven't had any really specific activity that I could say was on that theme, but it's certainly something that has come up for a number of years... We know from past experience that women often take on a bigger burden of care within the household, or many times it's the women who are somehow getting the household through the crisis, but at the same time doing all this other work...We worded it more in terms of work/life balance, but certainly that's a big part of it, needing to give more attention to women's role and care-giving (Interviewee 2).

We work with home-based care-givers within our AIDS campaign and that was why we decided to get involved in the CSW in such a big way. I would say that we don't focus so much on this equal sharing of responsibilities between men and women in terms of trying to promote men taking on greater responsibility, but rather we try to look at how to recognise and value and clear resources for women who are doing all of this huge work of care-giving, specifically as it has come out in the context of HIV and AIDS and the huge burden it has put on women in Africa (Interviewee 1). 
The 53rd session thus had to do a remarkable amount of conceptual and practical, movementbuilding work, gesturing to the aims of a diverse group of constituencies that had not previously been mobilized, to any significant degree, as an effective coalition in past CSWs.

Particularly crucial here was the successful construction of a linear policy narrative running across a wide range of past international agreements, wherein a new, combined emphasis on care, equal sharing and HIV/ AIDS was legitimated in part via skilful creation of a policy story. The narrative identified a progression from the 1994 agreements on population and reproductive health in Cairo and the 1995 Beijing PFA to the 53rd session, via numerous other international conferences, on the grounds that they all reflected a global consensus on the importance of partnership between men and women which included the equal sharing of care. This reading of past agreements as about partnership between men and women has been a dominant narrative of UN gender work for several years, ${ }^{14}$ but it was adapted for the 2009 CSW to focus specifically on care-giving. For example, it was regularly asserted that previous conventions and treaties-especially the Convention on the Elimination of Discrimination against Women (CEDAW) - "provide a legal framework and a comprehensive set of measures for the promotion of equal sharing of responsibilities between women and men" (CSW 2009:1). Indeed the Chairperson of the CEDAW Committee asserted at the CSW that: "throughout its work, the Committee has emphasized that the elimination of discrimination against women is a collective responsibility, with men being especially important. Equal sharing in care-giving, particularly in family life, is critical to providing an environment in which the objects of the Convention can be realized" (Gabr 2009:2).

This narrative, identifying a nascent UN "policy and legal framework...on the need to ensure more equal sharing of responsibilities between women and men" (DAW 2009b:1) and applying it to care-giving, proved extremely successful. It was repeated, in a virtually "cut and paste" fashion, on the CSW web site; in the background document put out in advance of the CSW (DAW 2009b:1); in the Secretary-General's Report to the 53rd session (Secretary-General 2009a:3), and in the preamble to the Agreed Conclusions (CSW 2009:1). ${ }^{15}$

Those involved in drafting this language are well aware that they need to achieve a balance between carrying on past commitments in order to move, in innovative ways, toward what might otherwise be seen as new goals (in this case, forging a new international policy agenda on care). This balancing act is a task in which UN gender policy entrepreneurs and Member State representatives are skilled. They have to work within the parameters of previously agreed language, since there have been fierce fights at past UN events over the alleged extension of gender equality instruments to cover controversial topics such as sexual and reproductive rights, and strong attempts to ensure that no "new rights" are conferred through the UN process. ${ }^{16}$ Hence as one interviewee noted in relation to the interstate negotiations:

It was very much a discussion about what is agreed language. I didn't know this expression before, but agreed language is a very central concept that means that the way you formulate a conclusion has to be agreed by everybody, so you go back to formulations that you had like in the Beijing PFA or in some formal document, then you have agreed language and this is how it works. Then you have a greater chance that everybody agrees because they did already agree once to a formulation (Interviewee 4).

\footnotetext{
${ }^{14}$ Yakin Ertürk (a previous director of the DAW and, until July 2009, the UN's special rapporteur on violence against women) used it in a 2004 article on the background to the CSW session on the role of men and boys, noting that the 1994 United Nations International Conference on Population and Development (ICPD) emphasized male inclusion in sexual and reproductive health and rights and the sharing of domestic chores, and that the PFA emphasized the need to engage men as partners, a commitment reinforced at the FiveYear Review of the Implementation of the Beijing Declaration and Platform for Action (Beijing +5) (Ertürk 2004:4).

15

For other examples of its deployment, see the statement from the Group of 77 and China (Mohamed 2009:2), and from the European Union (Kocáb 2009:1).

${ }^{16}$ For more on agreed language, the struggles to reaffirm the PFA, and the struggles to prevent "new rights" being established through the United Nations, see Buss (2004); Buss and Herman (2003); Sheill (2008).
} 
The obvious tension here over how advocates are to move forward to include previously ignored topics is resolved, in part, by constructing dominant policy narratives that tell a story of consensus, continuity and progress. The tension is captured perfectly in this remark from a CSW participant:

The general introductory part (of the Agreed Conclusions), which we call the
preambular, will include a lot of recognising documents from the past,
commitments from the past and so on. Some people who read the Agreed
Conclusions say, 'Why is all that there because it's not really related to the
theme?' It's very important, because it sets the basis. We sometimes have had
occasions where commitments are in jeopardy and so it's very important for
Member States to reaffirm, to recommit, to say, 'This is the basic starting
point.' Because, actually, what we are doing in the Agreed Conclusions is
trying to move forward. We are trying to push the global policy agenda
forward (Interviewee 8 ).

Likewise, as Annalise Riles notes in her ethnographic account of UN gender processes, a key aim of international forums such as the CSW is to get language repeated from one conference to the next in order to create international norms and retain previous advances. In this crucial work to move forward and prevent the roll-back of past commitments, documents are layered upon others in the "wearisome and often highly frustrating detailed work of cutting and pasting, of organizing and collating. One slowly work(s) the text together, phase by phrase, heading by heading" (Riles 2000:79). It is possible to rely on previously agreed UN texts in this regard, but at the same time one cannot borrow wholesale from past documents to create something new (Riles 2000:88) - this is a balancing act that participants learn from experience (pp. 80-81). In addition, several interviewees noted the skill of the main facilitator at the 2009 CSW negotiations, who "provided language where he thought it was going too slowly or where he felt there was really consensus, but it just needed a little bit of tweaking" (Interviewee 8).

Using this understanding of the labour and expertise involved in the creation of UN gender equality agreements, this paper suggests that the 53rd CSW is a prime example of how various collectivities were mobilized through construction of a frame about what past agreed language on gender equality meant. In other words, the theme used in this CSW was defined as having a history of consensus such that a wide range of constituencies were tied together, and held together, throughout the negotiations. The frame was a resonant one, connecting with the interests of several groups through embracing existing relationships to other ideas, actors and actions (Marx Ferree 2009:92). To give just a few examples, groups who submitted statements in support of the theme included a women's NGO that advocated "channeling national wealth from arms trade and military spending to care, health, education and welfare" (International Alliance of Women 2008:2); a missionary organization fighting AIDS in Africa (Associazione Comunità Papa Giovanni XXIII 2008:2); the Minister of Youth in Barbados, who highlighted the importance of participatory workshops for men in achieving gender equality (Byer-Suckoo 2009); a representative from the Botswana Ministry of Labour who emphasized the need for guidelines on home-based carers (Tsiane 2009:1); and the Cuban delegate, who attributed the problem of care in part to a drain of medical personnel from the Global South (Núñez Mordoche 2009:1).

To clarify, it is not suggested that the choice of the theme was intended, ahead of time, to appeal to this diverse set of interests, or to bridge feminists, workers' rights advocates, HIV/AIDS specialists and Christian missionaries. This reading would ignore the often unconscious ways in which tacit normative assumptions shape policy appeals (Lombardo et al. 2009b:11) ${ }^{17}$ The paper argues, more simply, that the frame of care proved an exceptionally expansive one, with enormous potential to mobilize support and bring potential opponents on board, particularly once it had been located within a broader arc of UN gender work on partnership.

\footnotetext{
${ }^{17}$ For more on debates about intentionality and policy framing, see Lombardo et al. (2009a), especially the contribution from Bacchi.
} 
In particular, by emphasizing care within the parameters of equal sharing of responsibility between men and women, the frame of the 53rd session appealed both to those interested in radically changing gender relations, and to more conservative parties interested in defending what they understand to be the natural family. To understand why and how this seemingly incongruous unity could have been achieved, it is helpful to recall Doris Buss and Didi Herman's (2003) analysis of the rise of Christian Right activism in the United Nations since 1995. This has involved an alliance of US Catholic, Mormon and Protestant conservative organizations to bring a "faith perspective" to UN work. ${ }^{18}$ This constituency invokes a crisis in the natural family at a global level, requiring international action through the UN orbit. Under the Presidency of George W. Bush, the US delegation to the 2002 UN General Assembly Special Session on Children included representatives from this Christian Right current, ${ }^{19}$ leading several analysts to reflect on the increasing power of natural family advocacy in the United Nations. ${ }^{20}$

The new US administration did not align itself with the Christian Right in the 2009 CSW, but nonetheless the continued presence of conservative Christian actors in the United Nations gender orbits is very clear, as is the resonance of the equal sharing of care frame with this audience. This is in part because care was seen by some as a way to take forward natural family politics. Consider, for example, the statement on the theme submitted to the Secretary-General by the Holy See, which holds Permanent Observer status at the United Nations. This asserted that "to consider care as a fundamental aspect of life has profound implications", including that it "leads us to think of the relationship between man and woman in society as interdependent" (Migliore 2009:1). The international NGO Mothers' Union also submitted a statement supporting the theme; its members, "motivated by their faith...run grassroots initiatives that support marriage, family life and flourishing relationships within communities" (Mothers' Union 2008:2). The Anglican Consultative Council (ACC) ${ }^{21}$ also found that the theme resonated well with its faith-based activities; it started its statement to the Secretary-General with the sentence: "For Christians, care for others is their bounden duty" (ACC 2008:2), and it closed with a quotation from the Bible. ${ }^{22}$ The threats facing the family, and the need to enact a global policy agenda to protect it and provide support for care, is a core theme-the family is being stretched "to the breaking point" and "devastated" by ever-growing burdens of care (ACC 2008:2).

The language of care, when linked with the language of equal sharing of responsibility between men and women, can thus successfully mobilize a wide range of constituencies. It allows a diverse group of actors to get behind a new global gender policy priority, including actors who might otherwise be hostile to UN gender efforts. This expansive frame helped facilitate many of the achievements noted below, and it renders the care rubric potentially very productive for gender advocates.

\footnotetext{
${ }^{18}$ Christian Right representatives from Latin America have increased in recent years, but the movement-at least as represented at the CSW-is still overwhelmingly US based.

${ }^{19}$ A senior fellow from Concerned Women for America was included on the official US delegation to this meeting (Buss and Herman 2003:143; Buss 2004:69). Delegates to the CSW appointed by Bush included Dorothy Bush Koch, sister of the President, and Liz Cheney, the Vice President's daughter; both spoke at the 48th Session of the CSW (Lauria 2004).

${ }^{20}$ For example, Buss and Herman (2003); Buss (2004); Sen (2005:20); Sheill (2008); Papademas (2004).

${ }^{21}$ The ACC is not usually considered part of the Christian Right at the United Nations, although recent debates about sexuality and gender in the Anglican Communion suggest the importance of Christian Right ideas among some members.

22 '"'Truly I tell you, just as you did it to one of the least of these who are members of my family, you did it to me.' The Gospel of Matthew 25:40" (ACC 2008:5). On the Christian nature of a lot of the care debate, see Cooper (2007).
} 


\title{
Section 3. Key Achievements
}

\section{Global recognition of care as a core political issue, especially in relation to HIV, for which governments are responsible}

\begin{abstract}
I urge you to be bold and ignite a new political momentum in order to turn the tide of the past decade and reinvigorate the world-wide gender equality agenda (Rachel Mayanja, Assistant Secretary-General/Special Adviser on Gender Issues and Advancement of Women, 2009:2).
\end{abstract}

The key objective of many of those involved in the 53rd session was to raise the profile of care issues and to put them on the international policy agenda. This objective was achieved with remarkably little contestation. As several participants noted, there was widespread support among Member States for key paragraphs regarding measuring care, integrating care into budgeting processes and so on, and civil society organizations coalesced to a remarkable extent:

Actually what was quite interesting for me, is that you know you sometimes get quite a lot of resistance from some of the women's rights people about the 'let's engage men' stuff, because of the diversion of resources and everything, but that didn't really seem to-I mean I literally heard nothing. So it's interesting, that seemed to be very uncontentious (Interviewee 11).

What is interesting is that the importance of care wasn't contested at all.... We had five pages of Agreed Conclusions presented by the Bureau (at the start of the second week), after the first reading of the text it was expanded to twenty-five pages. So a lot of delegations made a lot of amendments to the text. What was strange was that these amendments, they weren't really challenging the main contents of what was in the Agreed Conclusions. It was slight amendments in the sense of new aspects brought in (Interviewee 4).

This unity around the priority theme represents a significant shift from some previous CSWs. Analyzing the experiences of feminists involved in UN conferences in the 1990s and early 2000s, Gita Sen identified the period as one in which gender advocates had to struggle hard to maintain the gains of conferences in Vienna, Cairo and Beijing ${ }^{23}$ (Sen 2005:iii). In part as a result, the 2005 CSW (on a review of progress on the Beijing Declaration and PFA) was low key; it focused on reaffirming previous agreements rather than advancing the agenda (Molyneux and Razavi 2005:983). Much time was spent in the formal negotiations on the (unsuccessful) effort by the US delegation to specify that the PFA conferred no new international human rights, including no right to abortion, and the mood among gender advocates was characterized as defensive, sombre and cautious (Molyneux and Razavi 2005:984). The 2009 CSW, in contrast, was forward-looking, tackling a topic that had long been ignored and recommending concrete actions that, were they to be implemented, would radically alter existing policy.

This is especially significant in relation to HIV. Given the donor emphasis on treatment (heavily skewed towards anti-retrovirals), it has been hard for HIV/ AIDS organizations working on care issues to get their programming funded or scaled up as part of the global AIDS strategy. Ninety per cent of HIV/AIDS care-giving takes place outside of hospitals, and women do the majority of it, yet major donors had not been receptive to those trying to get funding for HIV/AIDS care strategy. As one participant pointed out:

Care-giving is always the thing that falls off the agenda. We talk about HIV prevention treatment and care, and there are specific policies on prevention and a whole thing on treatment. But really on care, we always say it, but what exactly is the package? What are we advocating for? (Interviewee 9).

\footnotetext{
${ }^{23}$ The 1993 World Conference on Human Rights, held in Vienna; the 1994 United Nations International Conference on Population and Development, held in Cairo; and the 1995 Fourth World Conference on Women, held in Beijing.
} 
The CSW represented an enormous step forward in this regard. Issues of care and HIV/AIDS were central to all the stages of work on the priority theme, and several country and regional statements raised concerns about home-based care and the inadequate resourcing of care compared to prevention and treatment. The United Nations Development Fund for Women (UNIFEM) and UNAIDS also collaborated in producing an expert paper for the 2008 EGM, setting the stage for a link between gender and HIV/AIDS work that would become one of the defining features of the 2009 CSW. Michael Sidibé, head of UNAIDS, addressed the March meeting with a rousing and inspirational speech that closed with an appeal for a new alliance of gender activists and HIV/AIDS activists on care issues: "My message and my appeal to you let us further unite the tremendous power of the women's movement with the AIDS movement" (Sidibé 2009:5). Several interviewees noted this intervention as one of the most important achievements of the CSW:

I think just the fact that UNAIDS was there and the Executive Director spoke at the opening - this was a really valuable opportunity for us (HIV/AIDS activists) to reach so many groups interested in issues of women. I don't know what other forum we could have gone to...to have that audience (Interviewee 9).

Moreover, in part because HIV/AIDS was a core component of the care conversation staged at the CSW, the meeting also forged a consensus that the equal sharing of responsibility between men and women within the private family is not enough to resolve the care problem. As the Director of the United Nations Research Institute for Social Development (UNRISD), Thandika Mkandawire, noted in his statement to the CSW:

The HIV/AIDS pandemic has been a tragic wake-up call to those who assume that families and communities - and more concretely women and girls - will continue to provide an unlimited supply of unpaid care to meet rising needs and to compensate for the shortfalls in policy. It is indeed out of a very difficult situation in those countries where there are very high rates of HIV/AIDS prevalence, and where there is enormous pressure on people's capacity to cope with care demands, that questions are being raised about the limits of relying on the unpaid work of girls and women (Mkandawire 2009:1)

This crucial lesson from HIV/AIDS was extended outward, and used to resist the idea that the care burden could be shouldered within families if men did more work. Several of the experts consulted for the CSW process had been concerned that discussions about care might ignore the role of the state, or put the blame for poor women's overwork on their poor male partners:

When we spoke to some of the experts and in particular the NGOs working on care, the main feedback is that it's not just about equal sharing, that equal sharing was not going to change fully the issues of the burden of HIV care on poor families in low-income countries. So while it's certainly is an issue, the solution wasn't just sharing it better between men and women, and then it would be okay (Interviewee 9).

Hence several of the papers submitted to the EGM explicitly made the argument that redistribution of care burdens to men was an insufficient solution. ${ }^{24}$ As one expert noted:

Gender inequality in the distribution of unpaid care work is not the only problem with care...Developing countries may face absolute care deficits, as some crucial care requirements are simply not met and neither families nor the community can compensate for state absence or retrenchment. In these circumstances, even 'equal sharing of responsibilities between women and men' would not suffice to provide the care required (Esquivel 2008:4, original emphasis).

\footnotetext{
${ }^{24}$ See, for example, Lewis (2008); Razavi and Staab (2008); Daly (2008).
} 
Or as the paper by UNIFEM and UNAIDS explained:

The redistribution of care work between men and women within the household or community is unlikely to sufficiently address the profound issues of poverty, strain and hardship of care-giving on families and households. Nor is it likely to meet the ever growing gaps in services and safety nets on the part of governments associated with health sector reforms, decentralization, privatization and cuts to social spending. (UNAIDS and UNIFEM 2008:9).

Several expert papers also criticized neoliberal policies that had attempted to reduce costs by overburdening the care sector, and hence harming care-givers and receivers. ${ }^{25}$ The final report of the EGM reflected these commitments (DAW 2008:9).

In turn the Secretary-General's report, which provided recommendations for consideration by the CSW and which is in many ways the most important document prepared in advance of the 2009 CSW, ${ }^{26}$ advocated a comprehensive approach from the start, involving improvements in labour market policies, health, education and infrastructure; efforts to tackle gender stereotypes, and efforts to measure and value unpaid work (Secretary-General 2009a:2-3). It also noted explicitly that the equal sharing of responsibilities between men and women was insufficient to resolve care dilemmas, ${ }^{27}$ a reference that one expert noted made her "pretty happy" (Interviewee 6).

These commitments to a strong government role were shared by a diverse range of stakeholders. UNRISD's statement to the Secretary-General noted that decision makers "will have to think very seriously about how public policies can help reduce the burdens of [care] work, to support those who carry it out and to complement it with other forms of caredelivered through public services, or state-regulated and subsidised provision by markets or not-for-profit providers" (Mkandawire 2009:1). It outlined five areas of policy action that clearly foreground the state's role: infrastructure, provision of social and care services, recognition of unpaid work in social security, social assistance; and decent wages and working conditions (Mkandawire 2009:3). The Executive Director of UNAIDS asserted that:

Redistribution of care-giving responsibilities is simply not enough. Women and girls need legislative and judiciary initiatives, policies and community driven programs. These are essential to ensure access to economic resources, social protection and safety nets, and access to education, skills training and employment (Sidibé 2009:4).

Bangladesh's country statement made the same point: that while efforts to enhance the involvement of men and boys in household and care work is important, the "increased share of care responsibilities between men and women alone is not adequate to address the persisting challenges of care giving. This has to be completed by an accessible and affordable sound public care service" (Jahan 2009:1).

Most importantly, the Agreed Conclusions lay out an extensive social policy roadmap on care that locates responsibility firmly with states. For example, they recommended that states should ratify key international agreements on the equal sharing of care, including ILO Convention 156 (which only 40 states have ratified) and that they should, among other measures:

\footnotetext{
${ }^{25}$ See, for example, Esquivel (2008); Addati and Cassirer (2008); Peacock and Weston (2008); UNAIDS and UNIFEM (2008).

26

Most Member States will read the Secretary-General's reports (2009a and 2009c), while they may not read the EGM report or other documentation (Interviewee 8). Moreover the Bureau prepares the first draft of the Agreed Conclusions based on the recommendations in the Secretary-General's report.

27 "Increased sharing of responsibilities between women and men will not, however, be adequate with respect to addressing the persistent challenges of caregiving in society. The HIV/AIDS pandemic has illustrated the need for the increased involvement in care work of all stakeholders-States, the private sector, civil society and households. Policy makers must recognize that care work is a critical societal function, contributing to the reproduction of society and to economic development. A multisectoral approach, including increased investment in quality public services, is needed to reduce the care burden on households" (Secretary-General 2009a:17-18).
} 
- design, implement and promote family-friendly policies and services, including affordable, accessible and quality care services for children and other dependants, parental and other leave schemes and campaigns to sensitize public opinion on equal sharing of employment and family responsibilities between women and men;

- measure, in quantitative and qualitative terms, unremunerated work and take measures to incorporate the value and cost of unpaid work within and between households and society at large in policies across all relevant sectors;

- ensure that social protection measures such as health insurance and child and family allowances are widely available and accessible, that workers are not discriminated against when they avail themselves of the benefits, and that these benefits target all workers, including, as appropriate, in the informal sector;

- develop and improve sustainable and adequate social protection and/or insurance schemes, including pension and savings schemes, and recognize leave periods for care-giving in the calculation of benefits;

- strengthen efforts to protect the rights and ensure decent work conditions for all domestic workers, including women migrant domestic workers;

- increase the availability, access to, and use of critical public infrastructure, such as transportation, the provision of a safe, reliable and clean water supply, sanitation, energy, telecommunications and affordable housing programmes, in particular in poverty-stricken and rural areas, to reduce the burden of care on households; and

- significantly scale up efforts towards the goal of universal access to comprehensive HIV/AIDS prevention programmes, treatment, care and support by 2010 and ensure that those efforts promote gender equality and take into account the care-giving responsibilities of both women and men (CSW 2009).

Securing these commitments from Member States was particularly important given the current financial crisis, and the danger - recognized by many at the CSW - that states might cut back on social provision and hence further overburden the care sector. The CSW's policy roadmap thus attempted to protect and extend care services during the global recession, which several actors agreed was significant. ${ }^{28}$

Importantly, faith-based organizations mobilizing to protect the family were fully signed up to this agenda as well. The Holy See urged governments to better protect immigrant care-givers, and to give professional training to home-based carers (Migliore 2009:2); and Caritas foregrounded the importance of social protection systems, of including home-based carers in shaping policy, and of states properly resourcing home-based care (Caritas and the National Board of Catholic Women of England and Wales 2008:3). Similar recommendations were made by the Anglican Communion (ACC 2008:4). After the Mother's Union had detailed its experiences with a Worldwide Parenting Programme that aimed to improve parenting skills and increase the equal sharing of responsibilities within families (Mother's Union 2008:3), it too advocated a holistic approach involving government support for flexible working practices, parental (particularly paternity) and carer's leave, and improved childcare provision (Mothers' Union 2008:4). Although the religiously inflected language of supporting family life is distinctive, these recommendations look very similar to those promoted by organizations with very different approaches to gender equality, such as the International Planned Parenthood Federation, ${ }^{29}$ the ILO, ${ }^{30}$ and Sonke Gender Justice. ${ }^{31}$

\footnotetext{
${ }^{28}$ For example, the Secretary-General's report emphasized the particular importance of the state's role in infrastructure and social protection in a crisis context (Secretary-General 2009a:18), as did the CSW's backgrounder (DAW 2008:2).

29 "Caring for people living with HIV and AIDS can be a substantial responsibility that should be borne by the State" (International Planned Parenthood Federation 2008:3).

${ }^{30} \mathrm{See}$, for example, the ILO's favourable coverage of a trade union in Singapore operating an elder care collective and childcare services, and a South African public works programme that provides childcare as an essential service to foster employment and reduce poverty (Addati and Cassirer 2008:27).

${ }^{31}$ Sonke Gender Justice used its statement to criticize unfair trade and debt policy and the evisceration of public sector spending as a result of structural adjustment (Khumalo 2009:3; see also Peacock and Weston 2008).
} 
That such diverse actors are advocating for the enhanced role of states in providing support to care policy is a noteworthy development, indicative (among other things) of shifting alignments between free-market neoliberals, religiously motivated neoconservatives and gender equality advocates. As Gita Sen noted, in the 1990s much debate at UN conferences reflected a disconnect between issues of gender justice (defined as primarily about sexual and reproductive rights, although also involving other gender equality measures), and economic justice (on fairer practices around global trade, debt, financing for development and so on). The United States, under Clinton, advanced a strong neoliberal economic agenda while supporting women's reproductive and sexual rights, and his administration was, for Sen, "intransigent" in global economic negotiations on world trade and debt repayment (Sen 2005:1). Likewise some conservative faith-based actors aligned themselves with countries in the Global South on economic issues in the 1990s, while opposing sexual and reproductive rights in UN conferences (Sen 2005:9). Writing in 2005, Sen argued that George W. Bush had inaugurated a neoconservative era that opposed both gender and economic justice, leading to new and different dynamics in global negotiations (Sen 2005:11). The 2009 CSW, in turn, can be seen as a moment where economic justice concerns were placed centre stage in a gender justice forum. The understanding of care forged there, involving a fundamental challenge to free-market models of the economy, had the support of many religious conservatives, as well as many gender equality advocates who see economic concerns as central to their work.

As several interviewees noted, then, in terms of a policy roadmap, the CSW represents a tremendous step forward from the Beijing PFA:

Kate Bedford: What do you think were the major steps forward taken in the CSW on the issue of care?

Interviewee: Putting the issue on policy agenda, having a global dialogue and discussion on the issue of care-giving and its role in equality and really, the need to address it if we really care about moving towards gender equality. Increasing the recognition that this is a kind of a fundamental issue that needs to be addressed (Interviewee 3).

For me I think the thing that I think is the most important is that the conclusions were adopted at all. But then particularly important I think is the fact that the Agreed Conclusions insist on the importance of the societal role of care and care-giving. This is a step forward, because in an economic sense there are some [agreed] conclusions that insist on measuring, on researching, where we can show how important this unpaid care work is. I think this is very important for future debates on how our economy works (Interviewee 4).

Once the UN takes on the discussion and analysis of these sorts of issues, it raises the level of visibility of the issue and it also brings a seriousness to it, because I think that people are saying 'Well the UN thinks this is something we should be looking at, at least we need to check it out and see what it is all about.' And so it raises the visibility of the problem and it begins a much wider discussion of what is happening. That is sort of the legacy (Interviewee 10).

The Platform for Action raised this [care] several times as being a major constraint and the ICPD (Cairo) and the social summit [the 1995 World Summit on Sustainable Development, held in Copenhagen] did as well. And then, the fact is that really not much happened on that... So what we look at to see is, has this moved us forward globally in the context of what the Platform [for Action] was trying to say about the importance of equal sharing as a constraint on gender equality and empowerment of women. I think that, from my perspective, I'm really happy with it. The Agreed Conclusions are never perfect documents. I think you need to look at what elements are in there and compare back to the Platform or the outcome of the special sessions. I do think it is a significant step forward. We actually have now a policy framework. It doesn't mean it's perfect, but we have a global framework that Member States have agreed to and that we can keep using and that we can 
refer to in different contexts and that we will come back and assess... What will happen now, and we see it already happening, is that care-giving gets onto the policy agenda and it will be taken up in other intergovernmental contexts in the UN...In the General Assembly it will come up and so, in this way, having a globally endorsed condensed document on what needs to be done in relation to this will help us to move forward, because other functional commissions will pick it up and UN entities have to work on it. They will have to report back to the General Assembly next year on what they've been doing to actually try to implement these recommendations (Interviewee 8).

As suggested here, the CSW gave a far more directed and specific form to concerns about care at the UN level, and it raised the profile of those concerns in the international community.

\section{Strengthened NGO work on care}

The CSW also had a positive impact on civil society organizations working around care-giving, and it increased the voices of care-givers in UN policy debates. As one participant noted in relation to past unsuccessful efforts to get attention to care from major donors, "it was such a struggle, talking to donors, and them saying it's not a priority for us. For us, having this be taken up by the United Nations, it gave a real emphasis to care as an issue, it's great" (Interviewee 11).

Or as another observer put it:

I feel sometimes that we don't look beyond the intergovernmental process and reflect on how convenings such as the CSW have the potential to translate into changes at the country level. How does what is discussed in New York translate into what policy makers particularly would do differently when they return to their countries, and how do we track that? This is particularly important in countries where civil society groups may not have access to policy-making spaces. And so, for a lot of people when they come to meetings such as the CSW, especially policy makers in government, they have an opportunity to hear the voices of civil society, and may be hearing these issues for the first time. So, I find in that sense, CSW is a very important coming together (Interviewee 5).

This coming together was of course not accidental. The DAW holds the online discussion forum precisely to raise awareness among NGO groups about the priority theme, and to give people who cannot attend the March meetings a voice in the debate. Several UN entities also involved grassroots care-givers in their preparations for the CSW, and some care-givers attended the EGM and the CSW, sponsored by UN actors and international NGOs who were trying "to play a convening role for people who are really working on home-based care specifically" (Interviewee 1). One group of participants organized a Town Hall meeting at the CSW, involving policy makers, experts involved in the EGM, people working in national women's machineries, UNAIDS actors and care-givers themselves. The resulting diversity of experiences present in the room greatly enriched the discussions. For example one participant, an expert on HIV, learned about efforts under way in South Africa to professionalize home-based care provision, and she pledged to share that information with others in her ordinary work. While some interviewees were concerned that governments might not follow up on their commitments in the Agreed Conclusions, ${ }^{32}$ all agreed that civil society work on care had been given an enormous boost.

Several participants also pointed to concrete outcomes from the CSW. Some NGOs took the opportunity to criticize their own governments from the CSW venue, hoping that they would

\footnotetext{
32 The youth and relative inexperience of the diplomats sent to the CSW led some participants to express their concerns that "the CSW was probably not one of the most important issues within all the possible UN bodies" (Interviewee 4), while the systematic underfunding of the women's ministries attending the CSW reinforced fears that the follow-up would be less than complete.
} 
get wide coverage in the media. ${ }^{33}$ Others formed a new advocacy group, the Caregivers Action Alliance, with other international NGOs working on home-based care from a communitydriven perspective. Successful lobbying work was also undertaken by carers to influence the Agreed Conclusions, whereby language on making care-giver's voices central to policy debates was inserted.

Moreover, the Agreed Conclusions were regarded by many interviewees as an important new resource in their own activism. As one interviewee explained:

Whenever you have a document that's signed by national governments and endorsed, you can always use that in your advocacy when working with the government of that country. Even though the document is very aspirational, you can use it in advocacy, you know, one more tool in trying to push an agenda (Interviewee 9).

Or as another, who was more critical of the care rubric, argued:

The topics tend to be very palatable - they tend to be ones that could be made to be much more cutting edge, but it's a little of the lowest common denominator, it's coming out with whatever states can most agree on, but both what goes in and what comes out, they're diluted. For me the benefit is where tools come from the UN system that governments have agreed to, where back home at a national level, activists can hold their governments accountable to what those governments and those government representatives are saying publicly in global venues. For me it's about producing the tools that could be useful on a national or even regional or local level, it's not just about the words on a page that you see in print in the end of the day. So wherever there is stronger language, you are building an arsenal of tools. For me that is the project (Interviewee 14).

Or as yet another put it, reflecting on both the importance of crafting consensus-based language in the Agreed Conclusions and the potential for activists to use this language in country-specific ways:

I think what was very interesting for me is to see how such a large number of
countries with such different cultural situations, political agendas and so on,
how they can come to an agreement on these issues, an agreement that is,
after all, for me, a very astonishingly progressive agreement. For instance
regarding my country, there are many of these agreed conclusions that if they
were applied properly, we would have a much better situation for women. So
this was for me really fascinating to see: how after one week of debates and
disagreements and clashes of all these differences that were present on the
table, finally these countries come to a conclusion. This is an interesting
process, and I learned how important this language issue is. To have, like, a
coin that is convertible in every country, so to say. And I think this is a very
interesting process for me also as a feminist, to see how on this international
level a process of standard production is going on, that we could profit much
more, or benefit from much more, if we were to understand it better here in
our country. For me when I came back, I wanted to have more ideas about
how to work with these texts (Interviewee 4 ).

Emphasizing these achievements, and the value of care as a "coin" in terms of policy entrepreneurship, is not to overlook the tensions evident at the EGM or the CSW. Some participants felt that inadequate attention had been given to issues such as gender stereotypes and the possibilities of changing men's roles; others felt that too much time had been spent on that issue, to the detriment of macroeconomic concerns; and yet others resisted the dichotomy between these two themes and felt frustrated that that they were still seen to progress at the expense of each other. There were some disagreements over whether HIV/AIDS should be the

\footnotetext{
33 For example, one NGO issued a press release from the CSW calling a minister to account for advocating harmful HIV/AIDS policies and providing inadequate support for prevention and treatment.
} 
focus of the discussion, or part of a broader conversation about care, and HIV/AIDS organizations are hardly unified themselves about the importance of gender equality measures in combating the epidemic. ${ }^{34}$ Another key faultline-familiar to those who had come to the CSW via involvement in feminist care debates - was whether women doing care work should be empowered by enabling them to do something else, or whether they should be given support and resources for their existing labour. ${ }^{35}$ Some poorer countries expressed frustration that debates about parental leave and family allowance distracted attention from their core concerns of labour-saving technology, adequate resourcing for care and the HIV/AIDS crisis (Gebreab 2009:2), and the Agreed Conclusions were also held up near the end of the negotiations in a dispute over preferred versions of the text.

However the three interviewees who spoke of this dispute agreed that, as one put it,

there were actually no huge substantive difficulties with the text...There were not huge thematic issues relating to the theme that were problematic. That's why we were able to move forward the way we did. If there had been huge things about unpaid work, sharing of unpaid work and care-giving, we would not have been able to do that, member states would not have agreed (Interviewee 8).

Likewise, consider these assessments from participants who hold very different positions on the debates about gender stereotypes, male inclusion and resourcing for women's existing care work:

So as long as someone says somewhere that equal sharing might not be enough, because you need resources and those resources should come from states, I am fine enough (Interviewee 6).

As a man I understand that we have to share responsibilities, and also you have to take care of members of your family and also provide support for families in need. But sometimes there are families that don't have the possibility to provide themselves, for their own care, so we need to construct a network of public services and also raise awareness in society, in the private sectors especially, to have these possibilities for families that don't have the sufficient funds or sufficient time to provide care for themselves (Interviewee 7).

The other big piece I was really pleased to see emphasized, especially at the EGM, is that there were lots of structural economists there who kept returning us to the task of thinking about the state, and not shifting this burden on to the shoulders of poor people, poor men, poor women...It was really nice to be in a room with people who were working structurally around these issues. It's part of the reason why I like working around the care economy, because it forces you to engage with the role of the state, with what structural adjustment has meant for the continent of Africa...If you do a lot of programmatic work, it's very easy to feel that those are ridiculous pie-in-the-sky things to be thinking about, especially if you are funded by [some major donors], who just don't really allow you to think about those kind of things very much in the way you do your work. So that was really nice (Interviewee 13).

It was such a great experience for me. This was about the fifth CSW that I've been to. Normally, I just sort of pop over to the UN and maybe we've organized a couple of workshops, but I've always thought it was not really relevant to what was actually happening with women working in poor communities. The fact that it was on care-giving was so important to so many women. Valuing care-giving, which is, in many ways, about women's

\footnotetext{
${ }^{34}$ See, for example, the critique of the dominant, biomedical approach to HIV/AIDS provided by Corrêa and Jolly (2008:27), an approach they characterize "as focus(ed) on technological quick fixes rather than social change".

${ }^{35}$ See, for example, the debates over the potential for exacerbating gender inequality by supporting women's existing care roles in Mkandawire (2009); Waring (2009:7); and Himmelweit (2008:13).
} 
knowledge and women's way of being, valuing care-giving is a huge step in really achieving the empowerment and equality of women, so I think that the topic is really important. And also so many people came to the UN and they created such a great energy around the CSW because of that topic (Interviewee 1).

Rather than resolving all conflict, then, what the 2009 CSW achieved was a consensus on: (i) the significance of care across the UN system, especially in relation to HIV, (ii) a strong state responsibility, and (iii) the centrality of care-givers' participation. This may prove significant in putting care on the policy agenda within the United Nations, in defending care services from state cutbacks in a recession, and in helping civil society actors mobilize around care (again, especially in HIV circles). ${ }^{36}$

\title{
Section 4. What the Care Conversation Could Enable in the Future
}

\begin{abstract}
It's supposed to be catalytic. It's supposed to, you know, create momentum and promote change, and I really hope that this will make a big difference, because it's so important...We have this opportunity, we should really try to make the most of that and try to engage other stakeholders as well. Maybe stakeholders who are not usually that engaged with the work of the CSW, but people who are working on this issue around the world to actually use this opportunity and take that framework and use it in different contexts and then report back to the CSW and maybe to think about, in a different way, what can be done. I think that these agreed conclusions actually give us a chance to do much much more work on this...Looking forward, it's a wonderful opportunity (Interviewee 8).
\end{abstract}

The paper closes by briefly noting two issues that received less attention in the 2009 CSW discussions: disability, and variations in kinship and intimate arrangement. I close with these issues because they help reveal current gaps in debates about care, which in turn allow consideration of the sort of interventions that might move conversation forward in future. This process of reflexivity about policy is a crucial component of feminist work on framing since, as Carol Bacchi (2009) and others note, we need critical reflection on hegemonic feminist approaches to ascertain how they may create borders or silence voices (in Lombardo et al. 2009b:9). Far from being a destructive enterprise, this process is intended to call existing work into question productively, by opening up terms and policy formulations to redeployment in ways that were not previously authorized (Butler cited in Lombardo et al. 2009b:9). The process is already a well-established part of the CSW's work, as one interviewee explained in assessing the efforts by DAW to put the Agreed Conclusions in an accessible format for a range of actors:

As we [gender advocates] come back to the theme, later on, we could also be raising gaps and things that should also be further developed, you know, kind of very logical next steps that come out. That's why we all want to get the Agreed Conclusions out broadly to people who are working on this and that's why, once they come out in the little brochure form, we are going to be sending this around to all the people who were engaged in different ways, to say, 'Can you take these and can you use them in whatever way you can, and can you also come back and feedback information on their usefulness, on areas which need further development?'...It's kind of an iterative process. You don't get everything you want the first time. But I think we've moved forward, so I'm really very positive that we got a good outcome. Really it depends on how we use it (Interviewee 8).

This section is intended as a contribution to this iterative process.

\footnotetext{
${ }^{36}$ Evidence to ascertain whether this potential has been converted into policy gains was not available at the time of going to press, although DAW will have a good sense of the usefulness of the Agreed Conclusions as a result of its outreach efforts in the next two to three years.
} 


\section{Disability and care: "The trend is upwards"}

Disability issues are starting to have their moment within the UN system. The Convention is great, it's an extraordinary thing.... The trend is upwards (Interviewee 14).

There were many reasons to expect that a UN-based conversation about care policy in 2009 would have disability firmly on the agenda, namely, because in 2008 the Convention on the Rights of Persons with Disabilities (CRPD) came into effect. This represented a significant, widely publicized achievement. As noted by the United Nation's disability rights office, it marked a:

\footnotetext{
'paradigm shift' in attitudes and approaches to persons with disabilities. It takes to a new height the movement from viewing persons with disabilities as 'objects' of charity, medical treatment and social protection towards viewing persons with disabilities as 'subjects' with rights, who are capable of claiming those rights and making decisions for their lives based on their free and informed consent as well as being active members of society. ${ }^{37}$
}

The convention constituted "the most rapidly negotiated human rights treaty in the history of international law"; 38 it has been signed by 142 countries, and ratified by 66, including China, Germany, India and the United Kingdom. President Barack Obama signed it in July 2009.39 The Convention includes binding agreements by states and other entities (such as the European Union) on care provision, and on the importance of including the voices of persons with disabilities in debates about care. As pointed out in an NGO forum on disability and poverty with special reference to the current economic crisis held at the 2009 Conference of States Parties to the CRPD, the Convention includes several relevant sections on care, development and poverty, including Article 26 (which guarantees all persons with disabilities access to voluntary rehabilitation in their community), Article 27 (on access to work), and Article 28 (on an adequate standard of living, including via coverage of disability-related expenses and the access of persons with disabilities, especially women and older people, to social protection and poverty reduction programmes) (International Disability Alliance 2009). One would thus have expected a foregrounding of disability debates within the CSW, and a significant presence of NGOs and UN entities working on the rights of persons with disabilities, gender and care.

However, there were only sporadic references to issues of disability in the CSW's 53rd session, and they stayed within the paradigm of framing disabled people as a care burden, alongside the sick and elderly (Secretary-General 2009a:3; CSW 2009:paragraph 9). The Agreed Conclusions mention persons with disabilities briefly, pledging to "strengthen, expand, improve and promote the accessibility of quality comprehensive public health care and services, including community-based health services specifically related to the prevention and treatment of HIV/AIDS, including for people with disabilities" (CSW 2009:7), but the theme is not mainstreamed throughout the text. While advocates for domestic workers and for home-based carers won crucial recognition for their struggles at the CSW and the latter were able to get language into the Agreed Conclusions about the importance of consulting with their community when deciding care policy, there was no acknowledgement of the voices or needs of persons with disabilities in debates about care. Disability was also sidelined within the preparatory processes leading up to the CSW, such as the EGM, and in the NGO parallel events.

\footnotetext{
${ }^{37}$ www.un.org/disabilities/default.asp?navid=12\&pid=150, accessed on 12 December 2009.

38 UN Deputy Secretary-General Mark Malloch Brown, in Adams-Spink (2006). See also Secretary-General (2009b).

${ }^{39}$ The rapid adoption of the CRPD stands in contrast to some of the other international agreements referred to in the CSW, which have achieved far lower levels of ratification: 40 countries have ratified Convention 156, for example, and China, Germany, India, the United Kingdom and the United States are not among them (Addati and Cassirer 2008:32).
} 
Kate Bedford: What about the issue of disability and care?

Interviewee: That's an interesting point, because I remember that came to my mind and I remember looking at the Convention [the CRPD] to see what was mentioned there in terms of care. It might have come up just a little bit. I don't think this was a major point (Interviewee 2, on the EGM).

Kate Bedford: Was there discussion of disability and care? Interviewee: Hardly at all. I mean no more than just occasionally recognizing, you know, 'oh, and disability and older people,' as if, kind of, 'throw it in there' - but not ever saying 'Okay, can we just talk about this issue for a moment?' (Interviewee 11, on the NGO events).

There are many possible reasons for this absence, including that the compromise text suggested by the facilitator toward the end of the negotiations dropped references to a number of issues that had been proposed during the debates. Disability, a topic which had been raised by countries including Australia, Canada and New Zealand, fell away at this stage. But the point remains that most Member States were ultimately unable to ascertain the relevance of disability concerns to the care conversation, unlike with other issues which had been successfully built in to the CSW process from the start such as domestic workers' rights, the needs of home-based carers and the importance of state services.

To clarify the significance of this neglect of disability activism and scholarship, it may be helpful to briefly sketch how some of the core assumptions behind the CSW's work on care would have been complicated by work on disability. For a start, the deployment of care as a normatively "good" concept that can bind diverse actors together in pursuit of a universally valued goal has been challenged by some disability researchers and activists, who regard the term care as oppressive, exclusionary and part of the problem they are mobilizing against. As Teppo Kröger notes in a recent review of the tensions between care research and disability research, "Care as a concept has symbolized a century-long confinement of disabled people to institutions and of lives controlled and colonized by others, by professional social workers and by care providers as well as by other family members" (Kröger 2009:403). Seen from this perspective, the concept of care locates power with the care-giver and promotes patronizing and disempowering attitudes to recipients of care, who are portrayed as a burden (Kröger 2009:404; Morris 1997). In turn, care research has too often identified solely with the needs of carers, distancing itself from the needs of disabled people (Kröger 2009:405). As a result "Resisting the terms 'care' and 'carer' has become a political act for disabled people" (Parker and Clarke 2002:351, original emphasis). Terms such as help, assistance and support, have been preferred by many, since these lack the "historical disrepute" or "the historical load of oppression and the invalidation of disabled persons" (Kröger 2009:407) associated with care.40

Second, the principle of self-advocacy - central to disability rights activism and scholarshipalso adds new perspectives to the CSW's debates about care. In self-advocacy, emphasis is placed on the fact that disabled people need human rights and control over their/our own lives (Kröger 2009:398), including choice and control over how any help or assistance necessary to facilitate independence is provided (Kröger 2009:405; Morris 2004:427). This results in a strong push for user-led or needs-led services, and the importance of giving people with disabilities (and others classified as "care receivers", such as older people and people living with HIV/AIDS) a central role in the planning and evaluation of care arrangements and polices (Kröger 2009:408).

Third, disability scholarship has provided new perspectives on the role of carers, both professional and informal, that would have been interesting to include in the CSW discussions. Finkelstein and others have developed compelling objections to the controlling approach that characterizes social care professionals working within dominant systems of service delivery directed at people with disabilities (summarized in Oldman 2002:793). Disability activism has

${ }^{40}$ See Oldman (2002:803) for reference to studies showing that older people also value help and not care. 
thus consisted, in many cases, of wrestling control away from care professionals (Oldman 2002:801). This sits uncomfortably alongside the fact that several Agreed Conclusions embrace the provision of more - unaltered - professional care services (CSW 2009:paragraphs aa, bb, and $\mathrm{mm})$. Likewise, there has been "deep and bitter controversy" over how family members and other informal carers are positioned in relation to the struggle for disabled people's rights (Ungerson 1997:46; Parker and Clarke 2002). Although ideas of "supporting carers" may be easier for policy makers to understand and accept than the more radical principles of empowerment for disabled people (Parker and Clarke 2002:355), listening to the voices of service users:

requires a much wider agenda than 'support for carers', although it does not say that we should not support them... Rather, this agenda asks us to question why so many older and disabled people have no option but to rely on family and friends to enable them to live 'in the community' and, therefore, why there are so many carers. It asks us to question whether anyone should have their continued ability to live in their own homes made dependent on the unpaid labour of those they love and who, they hope, love them. It requires... a direct challenge to those who see investment in carers' projects and respite care as 'cures' for the problem of delivering community care, rather than as the sticking plaster over a deep-seated problem (Parker and Clarke 2002:356, original emphasis).

An example is the way in which the issue of young carers has been treated in many advanced welfare states. The care literature on this topic has largely emphasized the burdens placed on children as robbing them of their childhood, further delegitimizing and devaluing disabled people as parents. This represents, according to many researchers and activists, a failure to analyse the deep-seated problem: that disabled parents are not receiving the assistance and support to which they are entitled, and which would enable them to maintain their independence. ${ }^{41}$ Until care activists and researchers actively engage with, and learn from, disability rights perspectives on such issues, there is serious danger that they will do harm. As Kröger's overview of the field summarizes:

The research that has concentrated on carers needs to learn that it is not enough to look only at the needs of informal and formal carers; this is because serving them may in practice mean the oppression and exploitation of disabled and older people, making them outsiders in their own lives. When developing support measures for family carers, this needs to be done in consultation and co-operation with people who are receiving care from them. Recognition for carers must not mean constructing disabled and older people as subordinate and passive persons (Kröger 2009:411).

Finally, the incorporation of a disability rights perspective into debates about care would bring new insights to debates over the role of the market in care, vis-à-vis other pillars of the "care diamond". There has been, for example, extensive debate in several countries (including Canada, Slovakia, the United Kingdom and the United States) over the issue of direct payments for personal assistance. Direct payments aim to transform care provision into a less personal, more formal relationship, where the disabled person gains power from being in an employer position, and hence can be better protected from the pejorative aspects of caring relationships (Kröger 2009:405). Since 2003, all social service departments in the United Kingdom have had a duty to offer direct payments to all eligible citizens (including disabled people, older people and parents of disabled children). This has been claimed as a victory by disability rights campaigners, who note that direct payments users have far more control than users of conventional, provided services, and are recognized as experts in defining and meeting their own needs for assistance and support (Rummery 2006:641-642). However, debate continues to rage over the problems of marketized delivery (Rummery 2006; Lyon 2005); the emancipatory and oppressive experiences of employee-employer relations; the limits of consumer choice in

${ }^{41}$ Parker and Clarke 2002:352; Kröger 2009:412; Morris 2004:434. 
terms of genuine empowerment (Spandler 2004:196); the need to defend robust collective service provision; and the tensions caused by the low level of payments, resulting in reliance on low-paid personal assistance workers vulnerable to exploitation. There were disputes among NGOs and experts at the CSW over the commodification of care, but these were restricted to well-worn debates over paying informal carers-none of the disability debates about neoliberalism and care were made central.

That said, however, the failure of the Agreed Conclusions to link up to the vibrant UN work on disability was noted by several interviewees as an obvious gap, and it was registered formally at the time as well: a press release from ECOSOC on 17 March noted that "delegates lamented that [the Agreed Conclusions] made no reference to the CRPD" (ECOSOC 2009:1). Moreover, as one participant noted, there is a clear common cause between disability rights advocates and HIV/AIDS activists to increase the voices of care recipients in the UN system:

There was very little discussion about care-receivers...The only people who were interested in that were the people who were coming from Africa who were working directly with AIDS, either with people suffering from AIDS or people working around care in a AIDS context (Interviewee 15).

Organizations working on HIV/AIDS from the perspective of sexual minority and sex worker communities have also struggled to get issues of self-advocacy, rights-based approaches, and user-led services accepted by major funders. As the World Health Organization (WHO) noted in a paper on the importance of tackling violence against sex workers in HIV/ AIDS struggles:

Interventions to promote safer sex among sex workers must be part of an overall effort to ensure their safety, promote their health and well-being more broadly and protect their human rights. There is also a need to recognize that not all sex workers see themselves as victims, oppressed or exploited. Instead, many can and are taking control of their own lives, finding solutions to their problems, acting in their individual and collective interests and contributing to the fight against HIV/AIDS. Some of the most successful sex work interventions have been led and run by sex workers and have allowed them to organize themselves for their own safety (WHO 2005:3).

This potential for "opportunities for mutual learning" (Kröger 2009:408) between HIV/AIDS, care and disability work has also been noted elsewhere. For example, the assumed boundary between those active subjects who give care and those passive objects who receive it-a binary that is to some extent repeated in the Agreed Conclusions - is troubled by some care research and by disability scholarship and activism. ${ }^{42}$ Although the conflicts between personal assistance workers and users of direct payment services are clear, some authors suggest that these groups may have a common interest in increasing the level of payments from the state, which will ensure better employee remuneration and less stress on the employer. ${ }^{43}$ This issue is of clear relevance to the ILO's efforts around dignified work. Others note the value of better collaboration between movements for disabled and older people, using the emphasis on userled practices and rights to services that facilitate an independent life (Kröger 2009:412). Organizations such as Help Age, which participated very actively in the CSW on care, are wellpositioned to consolidate such connections. These possibilities for cross-movement organizing, along with the high levels of state and NGO mobilization around disability in the global policy arena, suggest that a revisited CSW on care would forge better links between care and disability. It also raises the possibility that the United Nations ongoing disability conversations can draw on the 53rd session's Agreed Conclusions to push forward their own struggles around care provision.

\footnotetext{
${ }^{42}$ Some feminist care researchers have emphasized the universal nature of human dependence and the interdependence characterizing social relations (Williams 2001), and disability research has long challenged the idea of independence as self-sufficiency (Fine and Glendinning 2005), while also highlighting the care done by many people regarded as "dependants", especially disabled women who may be providing much of the care in their homes (Parker and Clarke 2002:351).

43 Rummery 2006:643; Ungerson 1997:45; Spandler 2004; Kröger 2009.
} 


\section{Diversity of family formations in care conversations}

In some parts of the negotiations, delegations proposed language on various forms of the family, for example, but after more negotiations these kinds of language disappeared. Instead it was replaced by family kinship and community responsibilities. That is because some of the delegations understand that various forms of the family is contrary to the view that there is one family, meaning, one man and one woman and that's it. That kind of change in the language is usual, sometimes it is common to see in the negotiations, because many delegations prefer a straight language and not a language that can be interpreted in one way or another (Interviewee 7).

Explicit recognition is important. We all know that what is unnamed is more likely to be unsupported, ignored and misunderstood (Paul Hunt, UN Special Rapporteur on the right to the highest attainable level of health, on the importance of naming sexual rights in UN work. Cited in Cornwall et al. 2008:xi).

A second important gap in the Agreed Conclusions - although not necessarily in all the CSW'S conversations about care - was the diversity of family forms and kinship arrangements through which care is provided. The CSW'S official agreements strengthened the notion that the privatized nuclear family consisting of a male-female partnership, sharing care and paid work in an egalitarian way, is the ideal for better care and better development, albeit supported with stronger state services. For example, Member States pledged to "take appropriate measures to achieve equal sharing of work and parental responsibilities between women and men, including measures to reconcile care and professional life and emphasize men's equal responsibilities with respect to household work" (CSW 2009:4), and their conversations about family were largely limited to this model. Attempts to create space to discuss other kinship arrangements were less than successful.

This is most obvious in relation to sexual minorities, such as gay and lesbian communities. Although sexuality-based organizations are present at the CSW, and there were NGO sessions held at the 2009 CSW on sexual rights, in general the groups attending these meetings did not engage with the care agenda and saw it as unrelated to their work. Some of the experts consulted for the CSW mentioned same-sex families, and the final report of the EGM mentioned this issue (DAW 2008:10), but it was not taken up as a major theme of the 2009 CSW. Likewise the groups and individuals working to challenge dominant masculinities as part of gender and development initiatives repeatedly put the issue of homophobia on the agenda as something that needs to be tackled in working with men, both in presentations at the CSW and in statements submitted to the Secretary-General; 44 but these references were absent in the Agreed Conclusions. Similarly one participant recalled an NGO panel at the CSW that included a man relaying his experience of caring for his HIV-positive male partner: "it was brilliant and powerful and he spoke brilliantly, but I didn't see that kind of thing reflected more broadly in the discussions" (Interviewee 11).

This is unsurprising. The CSW, like other UN gender forums, has experienced conflict over sexuality since the mid-1990s, and the issue still threatens to divide Member States and provoke confrontation. ${ }^{45}$ As one participant put it:

\footnotetext{
${ }^{44}$ In fact men's groups appeared to have been the most consistent advocates for sexual minorities in the UN's care discussions. Consider, for example, the written statement submitted to the expert panel on mainstreaming from Sonke Gender Justice, a South African organization that works on gender issues. It endorsed ACT-UP's approach as a model of activism and advocacy (Khumalo 2009:4), and identified the connection between homophobia and rigid models of masculinity as a core principle of work with men and boys (Khumalo 2009:5).

${ }^{45}$ For more on how the UN "has become a veritable battleground" around sexuality and sexual rights (Cornwall et al. 2008:2), see Wilson (1996); Klugman (2000); Rothschild (2000); Sen (2005); Miller (2009); Rosenbloom (1996); Corrêa and Parker (2004); Petchesky (2005); Sheill (2008) and the collection Development with a Body (Cornwall et al. 2008). See especially Petchesky (2005) and Corrêa and Jolly (2008) on the diverse readings of Beijing and Cairo, regarding, on one hand, endorsement of sharing couplehood between men and women, and on the other, the advancement of an agenda focused on women's sexual autonomy.
} 
Ideally I'd be talking about lesbians and sex workers. That is really difficult in these environments, and we-meaning a small group of allies who are sexual rights advocates - we use every entry point we can. But it is also sometimes difficult because we know that to put in certain language in a particular area will elicit not only scrutiny but a fight, and a fight that could cost us elsewhere. So if we are trying to have a particular outcome without, sorry, I'm going to be crass, but without a dogfight around certain language, you know-I mean we pick and choose what our battles are going to be (Interviewee 14).

Moreover, as suggested above, the progress being made in carrying forward the global gender equality project via a unifying focus on care, and in moving beyond the fights of the last decade, is in part based on a consensus about a universal model of a male-female couple, and a silence about the fights around sexuality at Cairo and Beijing. A battle to get the language of sexual rights or sexual diversity into debate about care was thus one sexual rights activists were bound to lose.

What is perhaps more surprising is the fact that other references to the diversity of family formation and care provision also dropped out at the CSW. Gay, lesbian, bisexual, and transgender communities are not the only groups excluded from consideration when "family" is defined as about privatized nuclear units. In the NGO online discussion forum, the EGM (see especially Akintola 2008), the NGO sessions and formal statements to the Secretary-General, there was a lot of discussion of the role of grandparents in care, of female-headed households, of children caring for parents, and of extended family support. As one interviewee summarized:

[the issue of diverse family formation] came up a little, not as much as I expected, really. Same-sex families were mentioned a little bit but hardly. Women-headed households were strong, particularly of course because in a context of HIV/AIDS and poverty generally it's quite a strong theme. And also what came up was the cross-generational households, with grandparents and grandchildren, or perhaps other family members, yes that did come up, that came up particularly from the people directly working in the African context on HIV (Interviewee 15).

Several civil society organizations also raised the issue of child carers, female-headed households and grandparents providing care, ${ }^{46}$ and the CSW's background document included key recognitions of diverse family forms. A section on "innovative approaches to leave provisions and benefits" highlighted the value of leave for grandparents, and the importance of giving child support grants to a child's primary care-giver, "regardless of whether that person is the child's biological parent" (DAW 2009b:3). Crucially, the Secretary-General's report also made the issue of diverse family forms explicit:

When developing policies and programmes on household responsibilities, including caregiving, attention needs to be paid to statistical data on demographic change, including changes in fertility rates, ageing populations and household composition. In Colombia, for example, there has been an increase in female-headed households. In Europe, single-person households and single-parent families who cannot rely on immediate help from coresidents have increased (Secretary-General 2009c:8).

In response, a few references to extended families did make it in to the Agreed Conclusions, notably in a commitment to:

\footnotetext{
${ }^{46}$ See, for example, the statement from the American Association of University Women (2008:4) and others, recommending that states "[i]dentify and address the needs of girls heading households and children without parental care", the demand from Soroptimist International (2008:3) that governments "[e]nsure that child, and grandparent headed-households, have resources and support available to them", and the recommendation from the International Planned Parenthood Federation (2008:5) that states recognize "that various family structures exist".
} 
(bb) Develop and/or expand, and adequately resource, the provision of equitable, quality, accessible and affordable care and support services for all people needing care, including through community-based support systems, while ensuring that such services meet the needs of both caregivers and care recipients, bearing in mind the increased labour mobility of women and men, and, where applicable, kinship and extended family responsibilities, and the importance of adequate nutrition (CSW 2009:6, emphasis added). ${ }^{47}$

Yet this did not fundamentally disrupt the ideal of the sharing couple on which the care conversations hinged. As one participant noted in recalling the conversations about extended family units, older relatives, neighbours and so on in HIV/AIDS care: "what I don't see people doing is saying 'okay, if that is the case, why are still talking about this as if it's a nuclear family setup.' I'm not sure people were necessarily framing responses differently because of that recognition" (Interviewee 11).

This may be in part because many of those references were understood to be relevant to a small group of communities marked as indigenous, and hence as "traditionally" different from the nuclear family norm. As one observer noted in relation to the interstate negotiations:

extended households were mentioned several times. It was Australia and New Zealand and Canada who insisted on such formulations. They modified the text successfully so that these extended family constellations were also integrated, but I think they were thinking of indigenous people rather than of modern patchwork family situations and the female-headed household (Interviewee 4).

The failure to mainstream debates about diverse family formations may also be due to the prominent marking of those forms of care provision as problems. For example, the high proportion of female-headed households in some Latin American countries was identified as part of the problem to be solved by many observers, rather than as an indication of the need to fundamentally reassess how we are talking about family, care and intimate attachments. ${ }^{48}$ Similarly, one coalition of NGOs spoke of the social problems associated with "parentified children, especially girls" (Coalition Against Trafficking in Women and UNANIMA International 2008:2), noting that some turn to prostitution and brewing home-made alcohol to generate income (Coalition Against Trafficking in Women and UNANIMA International 2008:3). Family diversity is recognized here, but as a problem to be overcome.

However that was not always the case at the CSW; some far more positive discussion of diverse family formation occurred. The Secretary-General's report (2009a:7), for example, noted Swiss research that found unmarried couples shared responsibilities in a more egalitarian way than married couples. The ILO, in particular, emphasized the crucial role played by sisters, mothers, aunts, co-wives and daughters in care, and it too advocated the adoption of leave policies that widen the entitlement to parental leave to grandparents (Addati and Cassirer 2008:15). Several of the groups working on issues of HIV/AIDS were at the cutting edge of these debates, repeatedly bringing up how the experience of care in a context of HIV/AIDS had challenged stereotypes about what family meant. As one participant noted, referring to the mobilization of home-based carers, this constituency has revealed the sometimes glaring failures of family members to properly provide for the needs of the sick: "they need someone to care, but they don't have relatives, or the relatives neglect them, they don't visit, they don't clean their homes, they don't care about if they have something to eat, if they get their antiretroviral drugs, whatever" (Interviewee 16).

For another, "HIV has forced major changes in the ways that families function," including by, in some cases, increasing men's involvement in care, reinforcing the "need to stop describing men

\footnotetext{
${ }^{47}$ See also the reference to widows in CSW (2009:paragraph kk).

${ }^{48}$ For a long view of how female-headed households have been considered disempowered, even in feminist work, see Chant (2006).
} 
in the Global South in such monolithic, sometimes racist ways" (Interviewee 13). These HIV/AIDS activists were joined by civil society groups focused on the needs of ageing populations. In its statement to the Secretary-General, the American Association of Retired Persons (2008:3) highlighted its work with grandparents in the United States who are caring for children. Rather than framing this care arrangement, per se, as a problem, it too targeted inadequate resourcing stemming from a narrow definition of who counts as family as the key issue: "Grandmothers with sole responsibility for grandchildren are often not eligible to receive the child support grants that younger mothers obtain, yet, may have no other source of income to pay for food, clothing, or school-related costs" (American Association of Retired Persons (2008:3). On these grounds, it is clear that the issue of diverse family formation is already on the table in relation to care, sometimes as a problem, but sometimes in a more positive way, and that it is relevant to a number of constituencies. Honest language about diverse family formation thus appears long overdue.

The difficulties of staging this conversation should not, of course, be understated. Issues of disability rights and diverse family forms will, clearly, raise key questions for feminists and others about the consensus underpinning the Agreed Conclusions on care. For example, they open up potentially explosive conversations about what UN-agreed language on "partnership" between men and women in the family means, and about how care receivers are positioned in the emerging policy measures. They will also force activists and policy makers to grapple with an increasingly obvious problem in gender equality and care policy arenas: how to reconcile the enthusiasm for increasing men's involvement in families as fathers with recognition of diverse family formations and care arrangements. ${ }^{49}$ More broadly, taking diverse family formation on board as a topic will provoke debate about the role that conjugality should (or should not) play in determining care, another far from uncontroversial topic. ${ }^{50}$

However, while such conversations will be difficult, continued failure to acknowledge the diverse ways in which people express their family commitments and intimate attachments may block countries and civil society groups from seeing the relevance of the Agreed Conclusions to their work, since they may not consider the nuclear family unit an applicable framework. As one interviewee explained:

The issue of single female-headed households is a huge policy issue in Latin American countries. I think that sometimes the language in UN documents gets filtered or laundered a little bit to go back to this stereotype [of a nuclear family] in the same way that our institutions and policies somehow draw invisibly on other stereotypes we have. I think that people are very aware from their own national context, and because UN documents don't always acknowledge those issues, people from those countries where they are verywell, where they are touching on those issues all the time-they think that these issues maybe aren't too relevant to them.... You get these reactions that work-family is an issue for developed countries, industrialised countries and it's more of a luxury issue. But that's because the language that it's so often presented in is about this, you know, men went off to work and women stayed home and work became unequally valued. It just doesn't correspond to the history and to the family structure, to anything. But as soon as you start talking about migration, the disruption of extended households, you know, single-parent families, orphaned families, it resonates immediately. There wasn't so much discussion about it, because I think people are just already thinking about it from their national perspective. But there should be, there should be definitely so much more discussion of that and what that means in different contexts (Interviewee 3).

\footnotetext{
${ }^{49}$ Several UN actors spoke about the importance of men's involvement in families as fathers (Zukang 2009); and the Secretary-General's report mentioned numerous examples of countries taking measures to support and strengthen men's involvement in care-giving (Secretary-General 2009a:12-14).

50 See, for example, debates on forging new links between economic and sexual justice projects (referenced in Bedford and Jakobsen 2009); on feminist economics and sexuality (Barker 2009; Bergeron 2009) and on sexuality and development debates (Bedford 2009; Lind 2010).
} 
Perhaps this discussion will, eventually, happen through the interstate negotiations process, as more space is created to talk about diverse family formation in official UN forums. One participant was optimistic in this regard, suggesting that space is gradually being opened up to talk about alternatives to the privatized nuclear family in UN venues:

\begin{abstract}
When they [Member States] talk about non-traditional households, most people are talking about female-headed households, most people are talking about everything but same-sex households, but it's a process, and there's a trend towards increased use of that language, and as that trend evolves there will be greater likelihood to referencing same-sex households too. Ultimately I'm a believer in the upward trends of these battles... The backlash has been terrible, the backlash really has been terrible; however I think the trends are moving towards the kind of language, participation, and acceptance of marginalized communities, or non-traditional communities, you know, different people's lives (Interviewee 14, original vocal emphasis)
\end{abstract}

But perhaps the space will remain closed at that level, and instead the conversation about how care policy can be shaped to serve different people's lives will continue horizontally, among the NGOs who mobilized so successfully around care in 2009. They are able to use the Agreed Conclusions, the connections they made with other activists, and the momentum around care to move policy forward in a variety of directions, including this one should it be considered relevant to their activities.

\title{
Conclusion: Toward Some Reframing
}

This paper is both backward and forward looking, seeking a better understanding of the processes through which care emerged as such a powerful theme at the CSW, aiming to unpack what was achieved there, and trying to identify where conversation might usefully focus next. It has argued that the Agreed Conclusions can be used to demonstrate an emerging global norm of care. More specifically, the agreements forged by Member States at the 53rd session offer an unprecedented opportunity to harmonize global care policy around key principles of state responsibility for care, and the importance of including care-givers' voices in care debates. This potential for widespread agreement rests, fundamentally, on the fact that the priority theme was articulated in such an expansive manner. The achievements delineated in section 3 were facilitated by the successful mobilization of a narrative of consensus regarding the equal sharing of responsibilities within male/female partnerships, and the privileging of care-givers in policy debates. This allowed the discussions of care at the CSW to link up with the existing objectives of a wide range of actors, including conservative religious actors who might otherwise be hostile to gender equality measures. One can see a new coalition emerging here, committed to tackling economic injustice concerns as they relate to the inadequacy of care provision, and involving a critique of state retrenchment in welfare.

Notwithstanding the advances secured through this framing of care, those involved in the CSW were very concerned to continue the conversation, and to explore what the Agreed Conclusions might make possible to say and do around care issues in the future. To that end, the paper also highlighted two themes-disability and family diversity-which received little sustained attention at the 2009 CSW, and it tried to analyse how they might have aided the debates.

It is clear, on even the most cursory coverage of the literatures included here, that a substantial reframing of care will be necessary if disability and the diversity of family formation are to be included in future debates about care at the UN level. The challenges of these inclusions should not be underplayed. Taking disability and diverse family formation into account reveals some key limitations of current framings of care, and it troubles several core assumptions underpinning the Agreed Conclusions. These include the assumption that care is a universally endorsed concept, that care-givers are the key constituencies to be addressed by policy makers, and that certain intimate attachments (but not others) should be promoted by Member States. 
Unsettling such assumptions risks destabilizing the consensus around care that successfully held such a diverse range of actors together in 2009, a worrying possibility to those who see it as having potential for future gender work.

However, the paper has argued that the care conversations at the CSW would without question have benefited from attention to disability and sexuality concerns, in a number of ways. Hence I suggest on balance that reframing care debates to grapple with the limitations of the current consensus is likely to be a positive and productive endeavour. For example, taking disability and diverse family formation seriously would enable new approaches to care concerns to be forged and new coalitions to be envisaged, injecting new energy into the arena and strengthening the political support for policies to provide for the realities of human dependency and inter-relatedness. It becomes possible to imagine new frameworks bringing new actors on board, with perspectives that would enormously enrich a future CSW. 


\section{Bibliography}

Adams-Spink, Geoff. 2006. UN Adopts Disability Convention. BBC News. 13 December. http://news.bbc.co.uk/1/hi/in_depth/6173073.stm, accessed on 12 October 2009.

Addati, Laura and Naomi Cassirer. 2008. Background Paper. Paper prepared for the CSW Expert Group Meeting, United Nations Economic Commission for Europe, Geneva, 6-9 October. Doc. No. EGM/ESOR/2008/BP.2.

Akintola, Olagoke. 2008. Towards Equal Sharing of AIDS Caring Responsibilities: Learning from Africa. Background Paper prepared for the CSW Expert Group Meeting, United Nations Economic Commission for Europe, Geneva, 6-9 October.

American Association of Retired Persons. 2008. Statement. Submitted to the CSW, New York.

American Association of University Women et al. 2008. Statement. Submitted to the CSW, New York.

Anglican Consultative Council (ACC). 2008. Statement. Submitted to the CSW, New York.

Armstrong, Derrick. 2002. "The politics of self-advocacy and people with learning difficulties." Policy and Politics, Vol. 30, No. 3, pp. 333-345.

Associazione Comunità Papa Giovanni XXIII. 2008. Statement. Submitted to the CSW, New York.

Bacchi, Carol. 2009. "The issue of intentionality in frame theory: The need for reflexive framing." In Emanuela Lombardo, Petra Meir and Mieke Verloo (eds.), The Discursive Politics of Gender Equality: Stretching, Bending and Policymaking. Routledge, London.

Barker, Drucilla. 2009. Queering Care. Paper presented at Rethinking Marxism Conference, University of Massachusetts, Amherst, 5-8 November.

Bedford, Kate. 2009. Developing Partnerships: Gender, Sexuality, and the Reformed World Bank. University of Minnesota Press, Minneapolis.

Bedford, Kate and Janet Jakobsen, 2009. Towards a Vision of Sexual and Economic Justice. Barnard Center for Research on Women and the Ford Foundation, New York.

Bergeron, Suzannne. 2009. "An interpretive analytics to move caring labor off the straight path." Frontiers, Vol. 30, No. 1, pp. 55-64.

Buss, Doris. 2004. "The Christian right, globalization, and the 'natural family."' In Mary Ann Tétreault and Robert A. Denemark (eds.), Gods, Guns, and Globalization: Religious Radicalism and International Political Economy. Lynne Rienner, Boulder, CO.

Buss, Doris and Didi Herman. 2003. Globalizing Family Values: The Christian Right in International Politics. University of Minnesota Press, Minneapolis.

Byer-Suckoo, Esther (Minister of Youth, Family and Sports, Barbados). 2009. Statement. Submitted to CSW, New York.

Caritas Internationalis and the National Board of Catholic Women of England and Wales. 2008. Statement. Submitted to CSW, New York.

Chant, Sylvia. 2006. "Contributions of a gender perspective to the analysis of poverty." In Jane Jacquette and Gale Summerfield (eds.), Women and Gender Equity in Development Theory and Practice: Institutions, Resources, and Mobilization. Duke University Press, Durham, NC.

Coalition Against Trafficking in Women and UNANIMA International. 2008. Statement. Submitted to the CSW, New York.

Commission on the Status of Women (CSW). 2009. Report on the Fifty-Third Session (2-13 March 2009). Economic and Social Council Official Records, 2009 Supplement No. 7. Doc. No. E/2009/27E/CN.6/2009/15. United Nations, New York.

- 2006. Short History of the Commission on the Status of Women. www.un.org/womenwatch/daw/CSW60YRS/CSWbriefhistory.pdf, accessed on 14 October 2009.

Cooper, Davina. 2007. "'Well you go there to get off': Visiting feminist care ethics through a women's bathhouse." Feminist Theory, Vol. 8, pp. 243-260.

Cornwall, Andrea, Sonia Corrêa and Susie Jolly (eds.). 2008. Development With a Body: Sexuality, Human Rights and Development. Zed Books, London.

Corrêa, Sonia and Susie Jolly. 2008. "Development's encounter with sexuality: Essentialism and beyond." In Andrea Cornwall, Sonia Corrêa and Susie Jolly (eds.), Development With a Body: Sexuality, Human Rights and Development. Zed Books, London.

Corrêa, Sonia and Richard Parker. 2004. "Sexuality, human rights and demographic thinking." Sexuality Research and Social Policy, Vol. 1, No. 1, pp. 15-38. 
Daly, Mary. 2008. The Equal Sharing of Responsibilities between Women and Men, Including CareGiving in the Context of HIV/AIDS. Paper prepared for the Expert Group Meeting, United Nations Economic Commission for Europe, Geneva, 6-9 October.

Division for the Advancement of Women (DAW). 2009a. Background Note on the 53rd Session of the CSW. Mimeo.

- 2009b. UN CSW Backgrounder: The Equal Sharing of Responsibilities between Women and Men, Including Caregiving in the Context of HIV/AIDS. www.un.org/womenwatch/daw/csw/csw53/ media/CSW53_backgrounder.pdf, accessed on 24 July 2009

- 2008. The Equal Sharing of Responsibilities between Women and Men, Including Caregiving in the Context of HIV/AIDS: Report of the Expert Group Meeting. United Nations, New York.

Economic and Social Council (ECOSOC). 2009. Women's Commission Ends Session, Calls for Shared Responsibility for Caregiving between Men, Women in Context of HIV/AIDS, Reducing Care Burden on Households. 'News and Media Division, Department of Public Information, New York, 16-17 March.

Ertürk, Yakin. 2004. "Considering the role of men in gender agenda setting: Conceptual and policy issues." Feminist Review, Vol. 78, pp. 3-21.

Esquivel, Valeria. 2008. A "Macro" View on Equal Sharing of Responsibilities between Women and Men. Paper prepared for the Expert Group Meeting, United Nations Economic Commission for Europe, Geneva, 6-9 October.

Fine, Michael and Caroline Glendinning. 2005. "Dependence, independence or inter-dependence? Revisiting the concepts of 'care' and 'dependency'." Ageing and Society, Vol. 25, pp. 601-621.

Finnemore, Martha. 1996. "Norms, culture, and world politics: Insights from sociology's institutionalism." International Organization, Vol. 50, No. 2, pp. 325-347.

Gabr, Naéla. 2009. Statement by Chairperson of the Committee on the Elimination of Discrimination Against Women. Submitted to the CSW, New York.

Gaer, Felice. 2009. "Women, international law and international institutions: The case of the United Nations." Women's Studies International Forum, Vol. 32, pp. 60-66.

Gebreab, Luul. 2009. Statement on behalf of Eritrea. Submitted to the CSW, New York.

Goetz, Anne Marie. 1997. "Introduction." In Anne Marie Goetz (ed.), Getting Institutions Right for Women in Development. Zed Books, New York.

Hafner-Burton, Emilie and Mark Pollack. 2002. "Mainstreaming gender in global governance." European Journal of International Relations, Vol. 8, No. 3, pp. 339-373.

Himmelweit, Susan. 2008. Rethinking Care, Gender Inequality and Policies. Paper prepared for the CSW Expert Group Meeting, United Nations Economic Commission for Europe, Geneva, 6-9 October. Doc. No. EGM/ESOR/2008/ep.7.

International Alliance of Women. 2008. Statement. Submitted to the CSW, New York.

International Association of Schools of Social Work. 2008. Statement. Submitted to the CSW, New York.

International Disability Alliance. 2009. CRPD Forum: Informal Session on Disability and Poverty with Special Reference to the Current Economic Crisis. Background paper. New York. 3 September. www.internationaldisabilityalliance.org/advocacy-work/conference-of-state-parties/secondconference-of-states-parties-september-2009, accessed on 15 September 2009.

International Planned Parenthood Federation. 2008. Statement. Submitted to the CSW, New York.

Jahan, Ismat. 2009. Statement by Ambassador and Permanent Representative, Permanent Mission of Bangladesh. Submitted to the CSW, New York.

Kabeer, Naila. 2000. "From feminist insights to an analytical framework: An institutional perspective on gender inequality." In Naila Kabeer and Ramya Subrahmanian (eds.), Institutions, Relations, and Outcomes: Frameworks and Case Studies for Gender-Aware Planning. Zed Books, London.

Kabeer, Naila and Ramya Subrahmanian (eds.). 2000. Institutions, Relations, and Outcomes. Frameworks and Case Studies for Gender-Aware Planning. Zed Books, London.

Khumalo, Bafana. 2009. Written Statement to the Interactive Expert Panel on Capacity-Building for Mainstreaming a Gender Perspective. Submitted to the CSW, New York.

Klugman, Barbara. 2000. "Sexual rights in Southern Africa: A Beijing discourse or a strategic necessity?" Health and Human Rights, Vol. 4, No. 2, pp. 144-173.

Kocáb, Michael. 2009. Statement on behalf of the EU. Submitted to the CSW, New York. 
Kröger, Teppo. 2009. "Care research and disability studies: Nothing in common?" Critical Social Policy, Vol. 29, No. 3, pp. 398-420.

Laville, Helen. 2008. "A new era in international women's rights? American women's associations and the establishment of the UN Commission on the Status of Women." Journal of Women's History, Vol. 20, No. 4, pp. 34-56.

Lauria, Joe. 2004. "U.N. confers on protecting women from war's toll." WeNews, Thursday, 11 March. www.womensenews.org/story/international-policyunited-nations/040311/un-confers-protectingwomen-wars-toll, accessed on 9 Oct 2009.

Lewis, Linden. 2008. Equal Responsibility for Sharing and Care Giving with an Emphasis on Men and Boys. Paper prepared for the CSW Expert Group Meeting, United Nations Economic Commission for Europe, Geneva, 6-9 October.

Lind, Amy (ed). 2010. Development, Sexual Rights and Global Governance. Routledge, New York.

Lombardo, Emanuela, Petra Meir and Mieke Verloo (eds.). 2009a. The Discursive Politics of Gender Equality: Stretching, Bending and Policymaking. Routledge, London.

Lombardo, Emanuela, Petra Meir and Mieke Verloo. 2009b. "Stretching and bending gender equality: A discursive politics approach." In Emanuela Lombardo, Petra Meir and Mieke Verloo (eds.), The Discursive Politics of Gender Equality: Stretching, Bending and Policymaking. Routledge, London.

Lucas, Sylvie. 2009. Statement by President of ECOSOC at the Opening of the 53rd Session of the CSW. Submitted to the CSW, New York.

Lyon, Jane. 2005. "A systems approach to direct payments: A response to 'Friend or foe? Towards a critical assessment of direct payments."' Critical Social Policy, Vol. 25, No. 2, pp. 240-252.

Marx Ferree, Myra. 2009. "Inequality, intersectionality and the politics of discourse: Framing feminist alliances." In Emanuela Lombardo, Petra Meir and Mieke Verloo (eds.), The Discursive Politics of Gender Equality: Stretching, Bending and Policymaking. Routledge, London.

Mayanja, Rachel (Assistant Secretary-General/Special Adviser on Gender Issues and Advancement of Women). 2009. Introductory Statement. Submitted to the CSW, New York.

Merry, Sally E. 2000. Colonizing Hawaii: The Cultural Power of Law. Princeton University Press, Princeton, NJ.

Migliore, Celestino. 2009. Statement, Apostolic Nuncio, Permanent Observer of the Holy See. Submitted to the CSW, New York.

Miller, Alice. 2009. Sexuality and Human Rights: A Discussion Paper. International Council on Human Rights Policy, Versoix, Switzerland.

Miller, Carol and Shahra Razavi. 1998. Missionaries and Mandarins: Feminist Engagement with Development Institutions. Intermediate Technology Publications and UNRISD, London.

Mkandawire, Thandika. 2009. Statement by Director of the United Nations Research Institute for Social Development. Submitted to the CSW, New York.

Mohamed, Samia Ahmed. 2009. Statement on behalf of Group of 77 and China. Submitted to the CSW, New York.

Molyneux, Maxine and Shahra Razavi. 2005. "Beijing Plus Ten: An ambivalent record on gender justice." Development and Change, Vol. 36, No. 6, pp. 983-1010.

Morris, Jenny. 1997. "Care of empowerment? A disability rights perspective." Social Policy Administration, Vol. 31, No. 1, pp. 54-60.

_. 2004. "Independent living and community care: A disempowering framework." Disability and Society, Vol. 19, No. 5, pp. 427-442.

Mother's Union. 2008. Statement. Submitted to the CSW, New York.

Núñez Mordoche, Ileana. 2009. Statement of Cuba. Submitted to the CSW, New York.

Oldman, Christine. 2002. "Later life and the social model of disability: A comfortable partnership?" Ageing and Society, Vol. 22, pp. 791-806.

Papademas, Diana. 2004. "UN Commission on the Status of Women: United States Representation." Network News: The Newsletter of Sociologists for Women in Society, Fall edition, p. 28.

Parker, Gillian and Harriet Clarke. 2002. "Making the ends meet: Do carers and disabled people have a common agenda?" Policy and Politics, Vol. 30, No. 3, pp. 347-359.

Peacock, Dean and Mark Weston. 2008. Men and Care in the Context of HIV and AIDS: Structure, Political Will and Greater Male Involvement. Paper prepared for the CSW Expert Group Meeting, United Nations Economic Commission for Europe, Geneva, 6-9 October. 
Petchesky, Ros. 2005. "Rights of the body and perversions of war: Ten years past Beijing." UNESCO's International Social Science Journal, Special issue on Beijing +10, Vol. 57, No. 2, pp. 475-492.

Poguntke, Thomas. 2009. "Foreword." In Emanuela Lombardo, Petra Meir and Mieke Verloo (eds.), The Discursive Politics of Gender Equality: Stretching, Bending and Policymaking. Routledge, London.

Prügl, Elisabeth and Audrey Lustagarten. 2006. "Mainstreaming gender in international organizations." In Jane Jacquette and Gale Summerfield (eds.), Women and Gender Equity in Development Theory and Practice: Institutions, Resources, and Mobilization. Duke University Press, Durham, NC.

Razavi, Shahra and Silke Staab. 2008. The Social and Political Economy of Care: Contesting Gender and Class Inequalities. UNRISD, Geneva.

Riles, Annelise. 2000. The Network Inside Out. University of Michigan Press, Ann Arbor.

Rosenbloom, Rachel (ed.). 1996. Unspoken Rules. IGLHRC, New York.

Rothschild. Cynthia. 2000. Written Out: How Sexuality is Used to Attack Women's Organizing. IGLHRC/CWGL. www.iglhrc.org/publications/books/WrittenOut/index.html, accessed on 21 June 2001

Rummery, Kirstein. 2006. "Disabled citizens and social exclusion: the role of direct payments." Policy and Politics, Vol. 34, No. 4, pp. 633-650.

Secretary-General. 2009a. Progress in Mainstreaming a Gender Perspective in the Development, Implementation and Evaluation of National Policies and Programmes, with a Particular Focus on the Equal Sharing of Responsibilities between Women and Men, Including Caregiving in the Context of HIV/AIDS. CSW, 53rd session. United Nations, New York. 2-13 March. Doc. No. E/CN.6/2009/4.

- 2009b. Promotion and Protection of Human Rights: Convention on the Rights of Persons with Disabilities Status of the Convention on the Rights of Persons with Disabilities and the Optional Protocol Thereto. UN, New York. 7 July.

- 2009c. The Equal Sharing of Responsibilities between Women and Men, Including Caregiving in the Context of HIV/AIDS. E/CN.6/2009/2. United Nations, New York.

Sen, Gita. 2005. Neolibs, Neocons and Gender Justice: Lessons from Global Negotiations. Occasional Paper No. 9. UNRISD, Geneva.

Sending, Ole Jacob. 2004. "Policy stories and knowledge-based regimes: The case of international population policy." In Morten Bøås, Desmond McNeill (eds.), Global Institutions and Development: Framing the World? Routledge, London.

Sheill, Kate. 2008. "Sexual rights are human rights." In Andrea Cornwall, Sonia Corrêa and Susie Jolly (eds.), Development With a Body: Sexuality, Human Rights and Development. Zed Books, London.

Sidibé, Michel. 2009. AIDS and Gender Equality: A Time for New Paradigms. Statement submitted to the CSW, New York.

Soroptimist International. 2008. Statement. Submitted to the CSW, New York.

Spandler, Helen. 2004. "Friend or foe? Towards a critical assessment of direct payments." Critical Social Policy, Vol. 24, No. 2, pp. 187-209.

Staudt, Kathleen. 2002. "Dismantling the master's house with the master's tools? Gender work in and with powerful bureaucracies." In Kriemild Saunders (ed.), Feminist Post-Development Thought: Rethinking Modernity, Post-Colonialism, and Representation. Zed Books, New York.

Tsiane, Segakweng. 2009. Botswana Country Statement. Submitted to the CSW, New York.

Ungerson, Clare. 1997. "Give them the money: Is cash a route to empowerment?" Social Policy and Administration, Vol. 31, No. 1. pp. 45-53.

United Nations Joint Programme on HIV/AIDS (UNAIDS) and United Nations Development Fund for Women (UNIFEM). 2008. Caregiving in the Context of HIV/AIDS. Paper prepared for the CSW Expert Group Meeting, United Nations Economic Commission for Europe, Geneva, 6-9 October.

Waring, Marilyn. 2009. Written Statement Submitted to the Interactive Expert Panel. Prepared for the CSW, New York.

Williams, Fiona. 2001. "In and beyond New Labour: Towards a new political ethics of care." Critical Social Policy, Vol. 21, No. 4. pp. 467-493.

Wilson, Ara. 1996. "Lesbian visibility and sexual rights at Beijing." Signs, Vol. 22, No. 1, pp. 214-218. 
World Health Organization (WHO). 2005. Violence against Women and HIV/AIDS: Critical Intersections. Violence against Sex Workers and HIV/AIDS Prevention. Information bulletin 3. WHO and UNAIDS, Geneva.

Zukang, Sha. 2009. Statement of Under-Secretary-General for Economic and Social Affairs to the 53rd Session of the CSW. Submitted to the CSW, New York. 


\author{
UNRISD Programme Papers on Gender and Development \\ PP GD 7 Harmonizing Global Care Policy? Care and the Commission on the \\ Status of Women \\ Kate Bedford, February 2010 \\ PP GD 6 The Political and Social Economy of Care: The Republic of Korea \\ Ito Peng, October 2009 \\ PP GD 5 A Debate on the Public Role of Religion and its Social and Gender \\ Implications \\ José Casanova and Anne Phillips, September 2009 \\ PP GD 4 The Statistical Evidence on Care and Non-Care Work across \\ Six Countries \\ Debbie Budlender, December 2008 \\ PP GD 3 The Political and Social Economy of Care in a Development Context: \\ Conceptual Issues, Research Questions and Policy Options \\ PP GD 2 A Critical Review of Selected Time Use Surveys \\ Debbie Budlender, June 2007 \\ PP GD 1 Change and Continuity in Social Protection in Latin America: \\ Mothers at the Service of the State? \\ Maxine Molyneux, May 2007
}


Printed at the United Nations, Geneva GE.10-?????-February 2010-1,500 